\title{
NiCOTIANA TABACUM AS A POTENTIAL PLATFORM FOR THE PRODUCTION OF RECOMBINANT ANTI-TOXOPLASMA SINGLE- CHAIN VARIABLE FRAGMENT (scFv) ANTIBODY
}

\author{
Fatin Iffah Rasyiqah Mohamad Zoolkefli'ia, Pei See Go ${ }^{2 a}$, Boon Chin Tan ${ }^{3 b}$, Nur \\ Ardiyana Rejab $^{4 a}$, Rofina Yasmin Othman ${ }^{5 a, b, c}$ and Norzulaani Khalid ${ }^{6 a^{*}}$
}

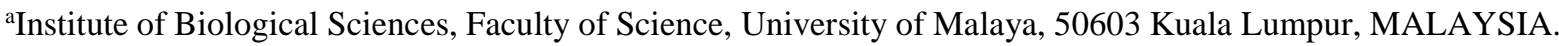 \\ Email: firasyiqahzoo190@gmail.com¹; gpeisee84@yahoo.com²; ${ }^{2}$ ardiyana@um.edu.my ${ }^{4}$; yasmin@um.edu.my ${ }^{5}$; \\ lani@um.edu.my ${ }^{6}$ \\ ${ }^{b}$ Centre for Research in Biotechnology for Agriculture (CEBAR), University of Malaya, 50603 Kuala Lumpur, \\ MALAYSIA. Email: boonchin@um.edu.my ${ }^{3}$; yasmin@um.edu.my ${ }^{5}$ \\ ${ }^{c}$ High Impact Research (HIR), University of Malaya, 50603, Kuala Lumpur, MALAYSIA. Email: \\ yasmin@um.edu.my ${ }^{5}$ \\ Corresponding author: lani@um.edu.my \\ Received: $13^{\text {th }}$ Jun 2019 \\ Accepted: $6^{\text {th }}$ Jan 2020 \\ Published: $30^{\text {th }}$ Jun 2020
}

DOI: https://doi.org/10.22452/mjs.vol39no2.1

\begin{abstract}
Plant systems have now gained much attention for recombinant therapeutic protein production. In this study, we aimed to evaluate the possibility of producing a single-chain variable fragment antibody ( $\mathrm{scFv}$ ), encoded by the TP60 gene, against Toxoplasmosis disease in Nicotiana tabacum cv. SR1. Toxoplasmosis, caused by infection of a parasitic protozoan known as Toxoplasma gondii, is one of the most prevalent parasitic diseases. Leaf explants of $N$. tabacum were infected with Agrobacterium tumefaciens strain LBA4404 harbouring binary vector pCAMBIA1304 containing TP60 gene. Bands observed at the predicted size of $914 \mathrm{bp}$ confirmed the presence of TP60 transgene, which was stably integrated into both $T_{0}$ and $T_{1}$ tobacco plant genome. FV12-6 transgenic line produced the highest mRNA expression (7-fold) correlated to the highest accumulation of anti- Toxoplasma recombinant $\mathrm{scFv}$ antibody $(0.52 \%$ of the total soluble protein), followed by FV16-10, FV177 , and FV3-11. Normal growth of the transgenic plants was observed. The segregation analysis of FV3, FV12, and FV16 in $\mathrm{T}_{1}$ generation confirmed the transgene integration within a single locus according to 3:1 Mendelian's law. These findings indicate the potential of using $N$. tabacum as a host system to produce TP60 recombinant protein without affecting the normal phenotype of the host plant.
\end{abstract}

\begin{abstract}
ABSTRAK Sistem tumbuhan kini telah mendapat perhatian bagi tujuan penghasilan protein terapeutik rekombinan. Dalam kajian ini, kami bertujuan untuk menilai kemungkinan menghasilkan antibodi serpihan rantaian variasi tunggal ( $\mathrm{scFv}$ ), yang dikodkan oleh gen TP60, terhadap penyakit Toxoplasmosis oleh Nicotiana tabacum cv. SR1. Toxoplasmosis, akibat jangkitan oleh protozoa parasit yang dikenali sebagai Toxoplasma gondii, adalah salah satu penyakit parasit yang paling lazim. Eksplan daun $N$. tabacum telah dijangkiti oleh Agrobacterium tumefaciens jenis LBA4404 yang menyimpan vektor dedua pCAMBIA1304 yang mengandungi gen TP60. Penjujukan yang kelihatan pada saiz ramalan, 914 bp mengesahkan kehadiran transgen TP60 yang telah terintegrasi secara stabil ke dalam genom
\end{abstract}


tanaman tembakau generasi $\mathrm{T}_{0}$ dan $\mathrm{T}_{1}$. Individu transgenik FV12-6 menghasilkan ekspresi mRNA tertinggi (7 kali ganda) berhubung kait dengan pengumpulan tertinggi scFv antiToxoplasma antibodi rekombinan ( $0.52 \%$ daripada jumlah protein larut), diikuti oleh FV1610 FV17-7 dan FV3-11. Pertumbuhan normal tumbuh-tumbuhan transgenik diperhatikan. Analisis segregasi FV3, FV12, dan FV16 pada generasi $\mathrm{T}_{1}$ mengesahkan integrasi transgen di dalam satu lokus menurut undang-undang Mendelian, 3: 1. Penemuan ini menunjukkan potensi $N$. tabacum sebagai sistem perumah untuk menghasilkan protein rekombinan TP60 tanpa menjejaskan fenotip normal tumbuhan perumah.

Keywords: Plant transformation, plant molecular farming, recombinant protein, single-chain variable fragment antibody ( $\mathrm{scFv}$ ), tobacco, toxoplasmosis

\section{INTRODUCTION}

Toxoplasmosis is a disease caused by the infection of a parasitic protozoan known as Toxoplasma gondii, which has economic implications due to neonatal loss and abortion in livestock animals (Elfahal et al., 2013; Stelzer et al., 2019). Efforts have been made to develop vaccines against $T$. gondii; however, only limited vaccines and anti-Toxoplasma drugs have been licensed for veterinary use. At present, only one commercial vaccine, Toxovax, which is based on live attenuated S48 strain, has been licensed for use to avoid congenital infection in ewes (Buxton \& Innes, 1995; Wen-Bin et al., 2019; Wang et al., 2019). The vaccine was previously developed to prevent the spread of disease in the sheep industry worldwide (Buxton \& Rodger, 2008). In addition, Toxovax has previously been used to reduce or eliminate the formation of infective tissue cysts in pigs for human consumption (Innes et al., 2011; Burrells et al., 2015). However, this vaccine is expensive and has a limited shelf-life. Furthermore, it may also revert to a pathogenic strain and may lead to an allergic reaction (Foroutan et al., 2019). T. gondii is capable of completing its life cycle without showing any symptoms of infection in feline as the host system. $T$. gondii is zoonotic and could be transmitted through saliva and faeces of infected feline.
Although it is usually asymptomatic in adults (Flegr et al., 2014), it can cause complications in immunocompromised persons (Wang et al., 2017) and pregnant women, which leads to congenital effects of newborn babies (Chaudhry et al., 2014). Therefore, this vaccine can have limited application for human use. Further efforts are needed to target this parasitic infection by focusing on the infection mechanisms of this parasite and how the host's immune system could combat this disease. Alternatively, developing recombinant proteins through various host systems would be of great value to human and veterinary medicine ( $\mathrm{Lim}$ et al., 2018; Puetz \& Wurm, 2019). To our knowledge, publications regarding the development of Toxoplasma antibody compared to vaccines are very minimal.

Antibodies are an essential component of protective immunity against the non-self antigen (foreign). Recombinant antibody fragments, such as single-chain variable fragment $(\mathrm{scFv})$, an alternative to fulllength monoclonal antibodies, have become useful in clinical practices due to the reduced size and simple expression in several systems while retaining their specific paratope (Farajnia et al., 2014; Lim et al., 2018). For instance, scFv with intact paratope has been successfully expressed in both prokaryotes and eukaryotes, such as 
bacteria (Sarker et al., 2019), mammalian cells (Omar, 2017), yeasts (Yuan et al., 2019), and insects (Kurasawa et al., 2012; Cérutti, \& Golay, 2012). Recently, a recombinant EBOV VP35 scFv monoclonal antibody has been found to significantly hamper the inhibition of the interferon- $\beta$ response, indicating its capability to control the spread of the virus (Flego et al., 2019).

Each host system has its advantages and disadvantages, depending on the experimental purposes and applications. Although most of the clinically available proteins and drugs are derived from mammalian cells, microbe, and yeast, the high demand for biopharmaceuticals coupled with the high costs and inefficiency of the existing production systems have limited the manufacturing capacity of these conventional cell-based expression systems. Moreover, the use of mammalian cells as a production host also raises concerns about its safety. Therefore, the approach of utilising plant host systems in the production of therapeutic proteins offers a lower production cost and lower risk of contamination compared to mammalian cells (Yao et al., 2015; Lim et al., 2018). In addition, the occurrence of post-translational modifications in the plant system ensures that the expressed recombinant proteins are correctly folded while maintaining their structural and functional integrity. The production of numerous complexes functional mammalian proteins, such as human serum proteins, growth regulators, antibodies, and vaccines, in plants have been reported (Obeme et al., 2011). For example, several therapeutic recombinant proteins against Ebola virus (Maxmen, 2012; Merlin et al., 2014; Sack et al., 2015), highimmunodeficiency virus (HIV; Niemer et al., 2014), West-Nile virus (Lai et al., 2014; Chen, 2015), H1N1 virus and its derivatives (Shoji et al., 2013; Cummings et al., 2014; Takeyama et al., 2015), and dengue virus (Kim et al., 2015; Amaro et al., 2015; Dent et al., 2016) have been published.

We hypothesised that tobacco plants could be used as a host system to produce TP60 protein. To test our hypothesis, we introduced and expressed TP60 protein in Nicotiana tabacum cv. SR1 mediated by Agrobacterium tumefaciens strain LBA4404. TP60 protein, encoded by TP60 gene, is a tachyzoite-specific single-chain variable fragment $(\mathrm{scFv})$ antibody that has been reported to show at least 1.8 -fold higher binding titres towards the target antigen of $T$. gondii compared to the parental antibody (Lim et al., 2012). The presence of the transgene in the transformed $N$. tabacum plantlets was then determined by transient reporter gene expression (GUS and GFP) and PCR analysis. Analysis of TP60 transgene in transgenic plants at the RNA and protein levels using semi-quantitative and quantitative real-time PCR (RT-qPCR) as well as Western blot, respectively, were carried out. Upon establishing a stable transformation of anti-Toxoplasma protein in $N$. tabacum, the segregation pattern of $\mathrm{T}_{1}$ generation has been analysed in addition to the phenotypic assessment between transgenic lines. These findings suggested that $N$. tabacum could be a potential host system to produce TP60 recombinant protein without affecting the normal phenotype of the host plant.

\section{MATERIALS AND METHODS}

\subsection{Vector construction, bacterial strain, and culture preparation}

The plant expression vector, pCAMBIA 1304 (http://www.cambia.org; CSIRO, Dickson, Australia) was used in the construction of a cassette containing anti-Toxoplasma scFv gene, TP60. The TP60 (accession no: KC508790.1) gene 
was obtained from the previous studies by Lim (2012) and Go (2013). The fragment was amplified from a pCANTAB 5E vector and ligated to pCAMBIA 1304 and transformed into Escherichia coli before being transformed into $A$. tumefaciens strain LBA4404 using a heat-shock method (Rahimzadeh et al., 2016). The T-DNA sequence in pCAMBIA 1304 vector contained hygromycin-resistant (hptII), mgfp5 (GFP), gusA (GUS), and target (TP60) genes fused with E-epitope tag sequence (GAPVPYPDPLEPR) driven by the CaMV 35S promoter (Figure 1). This construct was named as pTP60. Positively transformed colonies of Agrobacterium (verified by colony PCR with gene-specific primers, primer sequence listed in Table 1) were inoculated in $10 \mathrm{~mL}$ of liquid LuriaBertani (LB) medium with a ratio of 1:1000 containing $100 \mu \mathrm{g} / \mathrm{mL}$ kanamycin and 50 $\mu \mathrm{g} / \mathrm{mL}$ rifampicin (Duchefa, Haarlem, Netherlands) and incubated at $28{ }^{\circ} \mathrm{C}$ overnight under continuous shaking of 120 $\mathrm{rpm}$ in the dark before transformation. About $10 \mathrm{~mL}$ bacterial suspension culture with the optical density $\left(\mathrm{OD}_{600}\right)$ of $0.8-1.0$ was harvested by centrifugation at $5,400 \times$ $\mathrm{g}, 4{ }^{\circ} \mathrm{C}$ for $10 \mathrm{~min}$. The pellet was resuspended with $10 \mathrm{~mL}$ co-culture medium consisting of full-strength Murashige and Skoog (MS; Murashige \& Skoog, 1962) supplemented with $0.1 \mathrm{mg} / \mathrm{L} \quad \alpha-$ naphthaleneacetic (NAA) and $1.0 \mathrm{mg} / \mathrm{L} \mathrm{6-}$ benzylaminopurine (BAP).

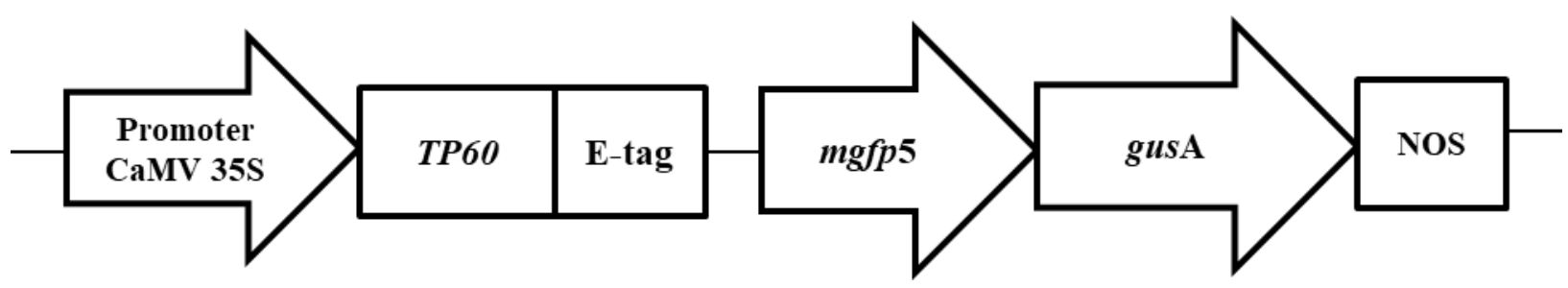

Figure 1. Diagrammatic representation of the pTP60 construct. Binary vector pCAMBIA 1304 as a backbone containing an anti-Toxoplasma scFv gene (TP60) fused with E-epitope tag (GAPVPYPDPLEPR), green fluorescence protein gene (mgfp5), GUS gene ( $g u s \mathrm{~A})$, and nopaline synthase terminator (NOS). This construct was driven by Cauliflower mosaic virus 35S (CaMV 35S) promoter.

\subsection{Plant materials and seed surface disinfection}

The seeds of $N$. tabacum cv. SR1 obtained from Academia Sinica, Taiwan, were soaked in $70 \%(\mathrm{v} / \mathrm{v})$ ethanol for approximately $30 \mathrm{~s}$ followed by rinsing with sterile distilled water twice. Surface disinfection was carried out by submerging and shaking the seeds in $25 \%(\mathrm{v} / \mathrm{v})$ Clorox $^{\mathrm{TM}}$ (containing $0.6 \%$ [w/v] of active reagent, sodium hypochlorite) for $20 \mathrm{~min}$ on a rotary shaker at $100 \mathrm{rpm}$ and rinsing six times with sterile distilled water (imbibition). The sterilised seeds were transferred to a Petri dish containing 25 $\mathrm{mL}$ of semi-solid MS medium (MSO) supplemented with $3 \%(\mathrm{w} / \mathrm{v})$ sucrose
(Sigma Aldrich, Germany) and $0.25 \%$ (w/v) Gelrite ${ }^{\mathrm{TM}}$ (Duchefa, Haarlem, Netherlands). All cultures were incubated at $25 \pm 3{ }^{\circ} \mathrm{C}$ under a 16 -h photoperiod with a light intensity of $20.3 \mu \mathrm{mol} \mathrm{m} \mathrm{m}^{-2} \mathrm{~s}^{-1}$ for about two weeks.

\subsection{Transformation and plant regeneration}

Prior to transformation, 4-week-old leaves of in vitro $N$. tabacum plantlets were cut into small discs $\left(\sim 1 \mathrm{~cm}^{2}\right.$ area $)$ and precultured on TSM medium (full-strength MS supplemented with $0.1 \mathrm{mg} / \mathrm{L}$ NAA, 1.0 $\mathrm{mg} / \mathrm{L}$ BAP, $3 \%$ [w/v] sucrose, and $0.25 \%$ $[\mathrm{w} / \mathrm{v}]$ Gelrite $^{\mathrm{TM}}$ ) and incubated at $25 \pm$ $3{ }^{\circ} \mathrm{C}$ under 16 -h light and 8-h dark cycle 
for three days. The leaf discs (nine explants per plate) were infected with Agrobacterium containing pTP60 construct for $10 \mathrm{~min}$, blotted dry on a sterile Scott ${ }^{\circledR}$ C-fold paper towel (Kimberly-Clark, USA) and co-cultured on TSM medium in darkness at $25 \pm 3{ }^{\circ} \mathrm{C}$ for two days. After co-cultivation, the infected explants with Agrobacterium harbouring pTP60 or pCAMBIA 1304 empty vector were transferred to TSMselection medium (MS medium supplemented with $250 \mathrm{mg} / \mathrm{L}$ cefotaxime and $20 \mathrm{mg} / \mathrm{L}$ hygromycin) until new shoots were formed. Hygromycin-resistant shoots were then transferred to TRM-selection medium (full strength MS medium containing $0.1 \mathrm{mg} / \mathrm{L}$ NAA, $3 \% \quad[\mathrm{w} / \mathrm{v}]$ sucrose, $0.25 \%$ [w/v] Gelrite ${ }^{\mathrm{TM}}, 250 \mathrm{mg} / \mathrm{L}$ cefotaxime and $20 \mathrm{mg} / \mathrm{L}$ hygromycin). The wild-type control plantlets were cultured on the same media without antibiotic supplementation. The wild-type and transformed plantlets with empty vector were used as a control. The transformation event was conducted in triplicate.

\subsection{GUS histochemical and GFP qualitative assays}

Hygromycin-resistant shoots (10week-old) were harvested and analysed using histochemical GUS (Jefferson et al., 1987) and GFP visualisation expression assays. GUS-stained tissues were examined under a stereomicroscope (Olympus, UK), whereas the expression of GFP was observed under a confocal laser scanning microscope (LEICA TCS SP5 II) with 20 oil-immersion objective lens. GFP expression was excited at the wavelength of $488 \mathrm{~nm}$ and detected through a filter for fluorescence wavelength of $550 \mathrm{~nm}$. Confocal images from the selected section within the upper and lower epidermis (using $\mathrm{z}$-stack) were merged using software (LAS AF version 2.3.1 build 5194 SP5). Wild-type tobacco leaves were used as a negative control to adjust the parameter of auto-fluorescence exclusion.

\subsection{DNA extraction and PCR analysis}

Total DNA were extracted from both $\mathrm{T}_{0}$ and $\mathrm{T}_{1}$ hygromycin-resistant and wildtype control shoots using DNeasy® Plant Mini Kit (Qiagen, USA) according to the manufacturer's instructions. The quantification of DNA were conducted using a NanoDrop 2000 UV-Vis spectrophotometer (Implen, Germany). PCR amplification of $\mathrm{T}_{0}$ hygromycinresistant shoots were performed using gene-specific primers, 1304-sk (Table 1) to confirm the presence of transgene with a predicted size of about 914 bp (iNtRON Biotechnology, Gyeonggi-do, South Korea). Amplification were performed using a Bio-Rad T100 Thermal Cycler (Hercules, CA, USA) under the following conditions: $94{ }^{\circ} \mathrm{C}$ for $2 \mathrm{~min}$, followed by 29 cycles of $94{ }^{\circ} \mathrm{C}$ for $20 \mathrm{~s}, 58.8^{\circ} \mathrm{C}$ for 20 $\mathrm{s}$, and $72{ }^{\circ} \mathrm{C}$ for $1 \mathrm{~min}$ followed by a final extension at $72{ }^{\circ} \mathrm{C}$ for $5 \mathrm{~min}$. The annealing temperatures of each pair of primer are stated in Table 1. The PCR products were visualised on ethidium bromide (EB)-agarose gel electrophoresis under UV Gel Pro Imager (Media Cybernetics, USA). Putatively transformed shoots with pTP60 construct and empty vector were amplified using GFP primers with a predicted size of about 750 bp (Table 1). The germinated $T_{1}$ seedlings ( $\sim 4$ to 5 weeks of germination) were screened using both 1304-sk and HPT1 primer pairs with the predicted size of $914 \mathrm{bp}$ and $559 \mathrm{bp}$, respectively. The PCR amplification were carried out similar to the $\mathrm{T}_{0}$ generation dependent on the annealing temperature, as stated in Table 1. 
Table 1. Primer sequences and PCR conditions

\begin{tabular}{|c|c|c|c|}
\hline Gene & $\begin{array}{l}\text { Accession } \\
\text { number }\end{array}$ & Primer, 5'-3' & $\begin{array}{c}\text { Annealing } \\
\text { temperatur } \\
\text { and } \\
\text { amplicon } \\
\text { length }\end{array}$ \\
\hline $1304-\mathrm{sk}^{\mathrm{A}, \mathrm{B}}$ & $\begin{array}{l}\text { Outside } \\
\text { target gene } \\
\text { region }\end{array}$ & $\begin{array}{l}\text { 5'-GAGAGAACACGGGGGACTC -3' } \\
\text { 5'-GTGCCCATTAACATCACCATC-3' }\end{array}$ & $\begin{array}{c}58.8^{\circ} \mathrm{C} \\
914 \mathrm{bp}\end{array}$ \\
\hline $\mathrm{GFP}^{\mathrm{A}}$ & AF234300.1 & $\begin{array}{l}\text { 5'-GGCTCGAGGACCATGGTAGATCTGACTAGA-3' } \\
\text { 5'-CTCGAGTCTAGAGGGGTTTCTACAGGACGTAAACT-3' }\end{array}$ & $\begin{array}{l}50.8^{\circ} \mathrm{C} \\
750 \mathrm{bp}\end{array}$ \\
\hline $\mathrm{HPT}^{\mathrm{B}}{ }^{\mathrm{B}}$ & AF234300.1 & $\begin{array}{l}\text { 5'-AGATGTTGGCGACCTCGTATTG -3' } \\
\text { 5'-GTTTATCGGCACTTTGCATCGGC -3' }\end{array}$ & $\begin{array}{l}55.0^{\circ} \mathrm{C} \\
559 \mathrm{bp}\end{array}$ \\
\hline $\mathrm{FV}-60^{\mathrm{C}}$ & KC508790.1 & $\begin{array}{l}\text { 5'-TGGAGTCCCTGATCGCTTCACTGGC-3' } \\
5 \text { '-GCTCCAGCTTGGTCCCAGCACCG-3' }\end{array}$ & $\begin{array}{l}60.0^{\circ} \mathrm{C} \\
149 \mathrm{bp}\end{array}$ \\
\hline $\mathrm{NtL} 25^{\mathrm{C}}$ & L18908 & $\begin{array}{l}\text { 5'-GGTTGCCAAGGCTGTCAAGTCAGG-3' } \\
\text { 5'-CCTTCCAGGTGCACTAATACGAGGG-3' }\end{array}$ & $\begin{array}{l}60.0^{\circ} \mathrm{C} \\
139 \mathrm{bp}\end{array}$ \\
\hline
\end{tabular}

\subsection{Acclimatisation of transgenic plantlets}

Ten PCR-positive individual transformants (represented by ten different lines) of $\mathrm{T}_{0}$ plantlets (12-week-old) with well-developed roots were washed thoroughly under running tap water and immersed in 1\% (w/v) IMAS-THIRAM 80 fungicide (Endona Corp, Malaysia) for at least $10 \mathrm{~s}$ before transferred to soil. The acclimatisation was conducted in a greenhouse (Plant Biotechnology Facility, University of Malaya, Malaysia) under 16- $\mathrm{h}$ photoperiod and incubated at $25 \pm 3{ }^{\circ} \mathrm{C}$. $\mathrm{T}_{1}$ seeds were collected for gene-stability analysis. Approximately 100-200 $\mathrm{T}_{1}$ seeds per line were germinated on MSOselection medium (full strength MS medium containing $3 \%[\mathrm{w} / \mathrm{v}]$ sucrose, $0.25 \% \quad[\mathrm{w} / \mathrm{v}]$ Gelrite $^{\mathrm{TM}}$ and $20 \mathrm{mg} / \mathrm{L}$ hygromycin). The percentage of $\mathrm{T}_{1}$ germination of each line was assessed and recorded. In addition, the phenotypes of three individuals of $T_{1}$ positive seedlings (four randomly selected lines) were examined and recorded (Table 2). 


\section{$2.7 \quad R N A$ extraction}

Total RNA from 40-day-old leaves of different $\mathrm{T}_{1}$ tobacco lines (FV3, FV12, FV16, and FV17) was isolated using the RNeasy® Plant Mini Kit (Qiagen, German). The total RNA was treated with RapidOut DNA Removal Kit (Thermo Fisher Scientific, USA) prior to RT-PCR. RNA integrity and concentration were assessed using EB-stained agarose gel electrophoresis and NanoDrop ${ }^{\circledR}$ ND-1000 Spectrophotometer (NanoDrop Technologies, Wilmington DE, USA), respectively.

\subsection{Semi-quantitative RT-PCR and quantitative real-time PCR analysis}

One $\mu \mathrm{g}$ of DNase-treated RNA were used in the cDNA synthesis. The firststrand cDNA was synthesised using RevertAid $\mathrm{H}$ minus First-strand cDNA synthesis kit with $10 \mu \mathrm{M}$ oligo-dT nucleotides (Thermo Fisher Scientific, USA). For reverse transcription quantitative real-time polymerase chain reaction (RT-qPCR), specific primers for FV-60 fragment amplification with a predicted size of $149 \mathrm{bp}$ were used. $N$. tabacum ribosomal protein L25 (NtL25) were used as the reference gene (Schmidt $\&$ Delaney, 2010; Table 1). Ten $\mu$ L of PCR reaction mixtures containing $5 \mu \mathrm{L}$ of 2 Power SYBR green (Thermo Scientific, USA), $1 \mu \mathrm{L}$ of $100 \mathrm{ng}$ of cDNA template, and $0.5 \mu \mathrm{L}$ of each forward and reverse primers at the final concentrations of 500 $\mathrm{nM}$ were amplified on an ABI QuantStudio $^{\mathrm{TM}}$ 12K Flex real-time PCR system (Applied Biosystems, Carlsbad,
CA, USA) under the following parameters: 10 min denaturation step at $95{ }^{\circ} \mathrm{C}$, followed by 40 two-step cycles of $15 \mathrm{~s}$ at $95^{\circ} \mathrm{C}$ and $1 \mathrm{~min}$ at $60^{\circ} \mathrm{C}$. A PCR mixture without template was included as the no template control (NTC). All amplifications were carried out in triplicates, and the data were analysed using the formula, $2^{-\Delta \Delta \mathrm{Ct}}$ (Bustin et al., 2009; Livak \& Schmittgen, 2001). For semi-quantitative RT-PCR, 100 ng cDNA were used as the template following a 3-step standard PCR amplification (iNtRON Biotechnology, Gyeonggi-do, South Korea) at the annealing temperature of $60{ }^{\circ} \mathrm{C}$ for both target (FV-60) and reference (NtL25) gene primers. The amplicon were visualised on EB-agarose gel electrophoresis under UV Gel Pro Imager (Media Cybernetics, USA).

\subsection{Protein extraction}

The leaves from the third to the seventh axial position of $\mathrm{T}_{0}$ and $\mathrm{T}_{1}$ tobacco plants of each line were harvested after 40 days of acclimatisation and ground into fine powder in the presence of liquid nitrogen (Robert et al., 2013; Figure 2). The powder (100 mg) was dissolved in 100 $\mu \mathrm{L}$ of 1 phosphate buffer saline (PBS; Thermo Fisher Scientific, USA) and incubated at room temperature for $5 \mathrm{~min}$ before centrifuged at $15,000 \times \mathrm{g}$ for $5 \mathrm{~min}$ at $4{ }^{\circ} \mathrm{C}$. The supernatant was transferred to a new $1.5 \mathrm{~mL}$ microcentrifuge tube and stored at $-80{ }^{\circ} \mathrm{C}$ until use (Lin, 2011). Quantification of total soluble proteins was assayed, according to Bradford (1976) using Bio-Rad Bradford Dye (Hercules, CA, USA) and bovine serum albumin (BSA) as a protein standard. 


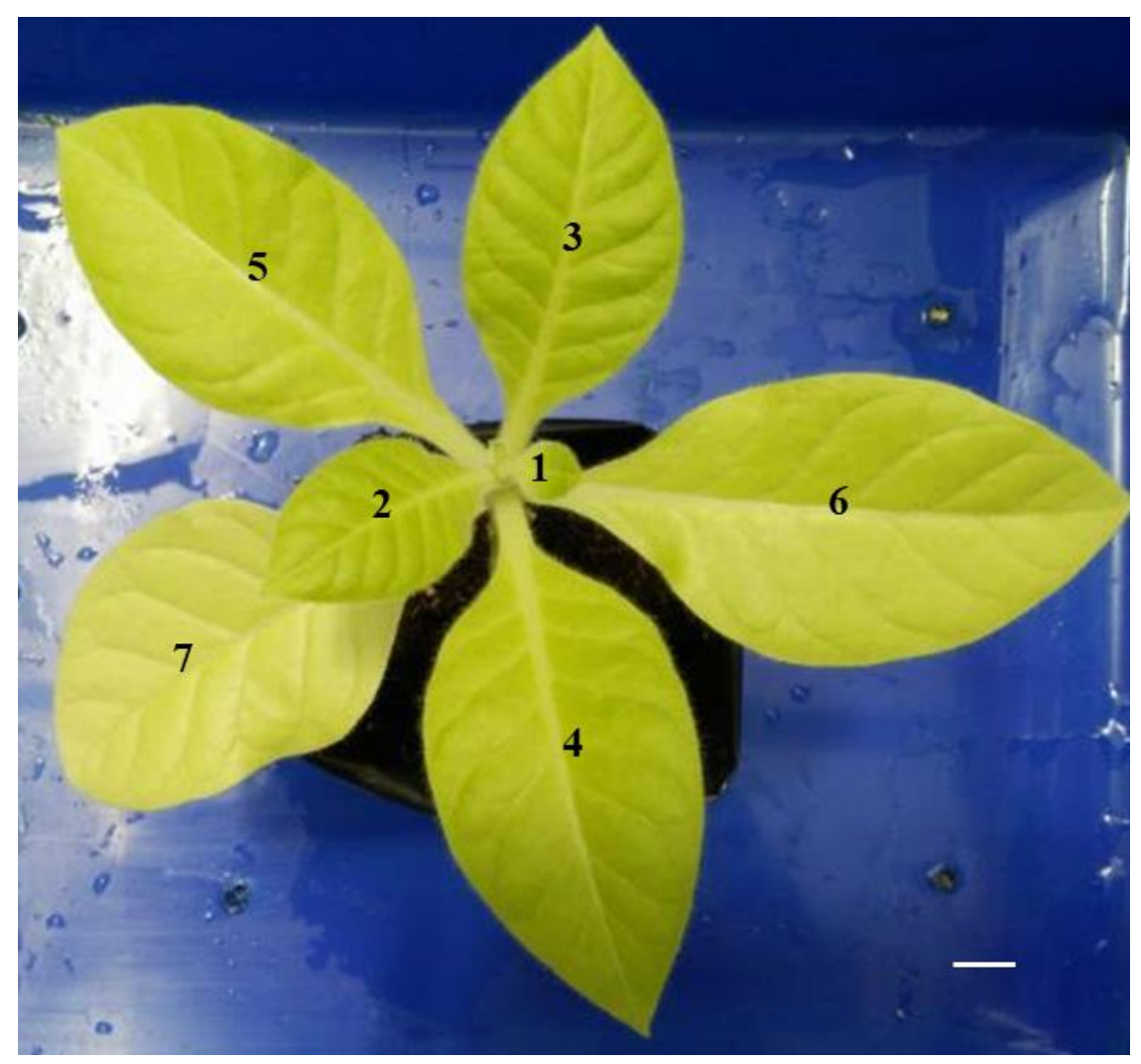

Figure 2. Representative of 45-day-old Nicotiana tabacum cv. SR1 $\mathrm{T}_{1}$ plant (aerial and leaves numbered from the apex down). $B a r=1 \mathrm{~cm}$.

\subsection{Protein purification and quantification}

Total protein of the representatives from each line was purified using Dynabeads ${ }^{\circledR} \quad$ M-280 Sheep anti-Mouse IgG (Invitrogen, USA) by coupling the beads with $2 \mu \mathrm{g}$ of target-Ig (Abcam Eepitope tag monoclonal antibodies), according to the manufacturer's instructions. The purified protein samples were then subjected to sodium dodecyl sulphate-polyacrylamide gel electrophoresis (SDS-PAGE) and Western blot analysis.

\subsection{SDS-PAGE immunoblotting}

About $25 \mu \mathrm{g}$ of total soluble protein extract and the purified protein were resolved on $12 \%(\mathrm{w} / \mathrm{v})$ SDS-PAGE in a reducing condition. The gels were either stained with SimplyBlue ${ }^{\mathrm{TM}}$ SafeStain (Invitrogen, USA) or transferred to the Amersham ECL Sensitive Nitrocellulose membrane (GE Healthcare, USA) using Bio-Rad trans-blot apparatus (Hercules, CA, USA) in Advansta Flash blot transfer buffer (Menlo Park, CA, USA), according to the manufacturer's instructions. The 
membrane was blocked with TBST buffer (1 TBS [Tris buffer saline; Thermo Fisher, USA] with $0.1 \% \quad[\mathrm{v} / \mathrm{v}]$ Tween 20) containing 5\% (w/v) BSA, pH 7.0 \pm 0.5 for $1 \mathrm{~h}$ followed by incubation in 1:1000 of diluted primary antibody, E-epitope tag monoclonal antibodies from immunised mouse (Abcam, Cambridge, UK) overnight at $4{ }^{\circ} \mathrm{C}$ with gentle agitation. The membrane was washed three times with TBST for $5 \mathrm{~min}$ each on the following day before incubated with 1:5000 diluted goat anti-mouse polyclonal IgG antibodies conjugated with horseradish peroxidase enzyme (HRP), Fc fragments (Abcam, Cambridge, UK), for $90 \mathrm{~min}$ at room temperature with gentle agitation. The membrane was washed three times with TBST for 5 min each and visualised with Advansta ECL Advansta WesternBright Quantum (Menlo Park, CA, USA), according to the manufacturer's instructions and imaged using Bio-Rad ChemiDoc Imager (Hercules, CA, USA) under white light.

\section{$2.12 \quad$ Statistical analysis}

The phenotypic assessments were conducted in triplicate and statistically analysed using one-way analysis of variance (ANOVA). The mean values of treatments were subjected to Tukey's multiple comparisons. The statistical analysis was performed using SPSS 16.0 (SPSS Inc., USA) at 5\% confidence level.

\section{RESULTS AND DISCUSSIONS}

\subsection{Regeneration and transient analysis of putative transformed shoots}

In this study, we aimed to express antiToxoplasma protein, TP60, in tobacco through Agrobacterium-mediated transformation. After co-cultivation, the leaf discs were recovered on the TSM selection media. About $20 \pm 0.33$ shoots which represent as transgenic lines were successfully regenerated from the transformed leaf discs. Non-transformed leaf discs turned brown and became necrotic on the selection media. Hygromycin-resistant shoots were randomly selected for GUS and GFP qualitative assays (Figure 3a). An intense blue colouration was observed on the putative transformed shoots after GUS staining (Figure 3b, c), whereas the nontransformed region on the same expanded putative transformed leaves remained colourless. The mechanism of mixing transformed and non-transformed cells within expanded putative transformed shoots might be due to the high frequency of chimeras in the leaf disc transformation, which can be eliminated by selecting the positive seedling in $\mathrm{T}_{1}$ progenies. Shoots transformed with pTP60 construct showed fewer blue spots on the expanded leaf (red arrow) compared to only pCAMBIA 1304 (Figure 3c). This indicated that the expression of GUS gene was decreasing due to the addition of TP60 gene insert after the CaMV $35 \mathrm{~S}$ promoter. The putative transformed shoots were then examined for green fluorescence to determine the expression of the $m g f p 5$ gene (Figure 3d).

The non-transformed region of the same expanded putative transformed shoots showed red colouration (Figure 3e) due to auto-fluorescence under UV light in the presence of chlorophyll background signal (Goldman et al., 2003; Zhou et al., 2005). According to previous publications, following the recovery of a new putative transgenic plant, GFP fluorescence was usually visible in new emerging shoots, young tissues or organs, whereas weak signal was observed in older ones (Zhou et al., 2004), such as in Medicago truncatula var. A17 (Kamaté et al., 2000) and Verbena officialis L. (Tamura et al., 2003). 

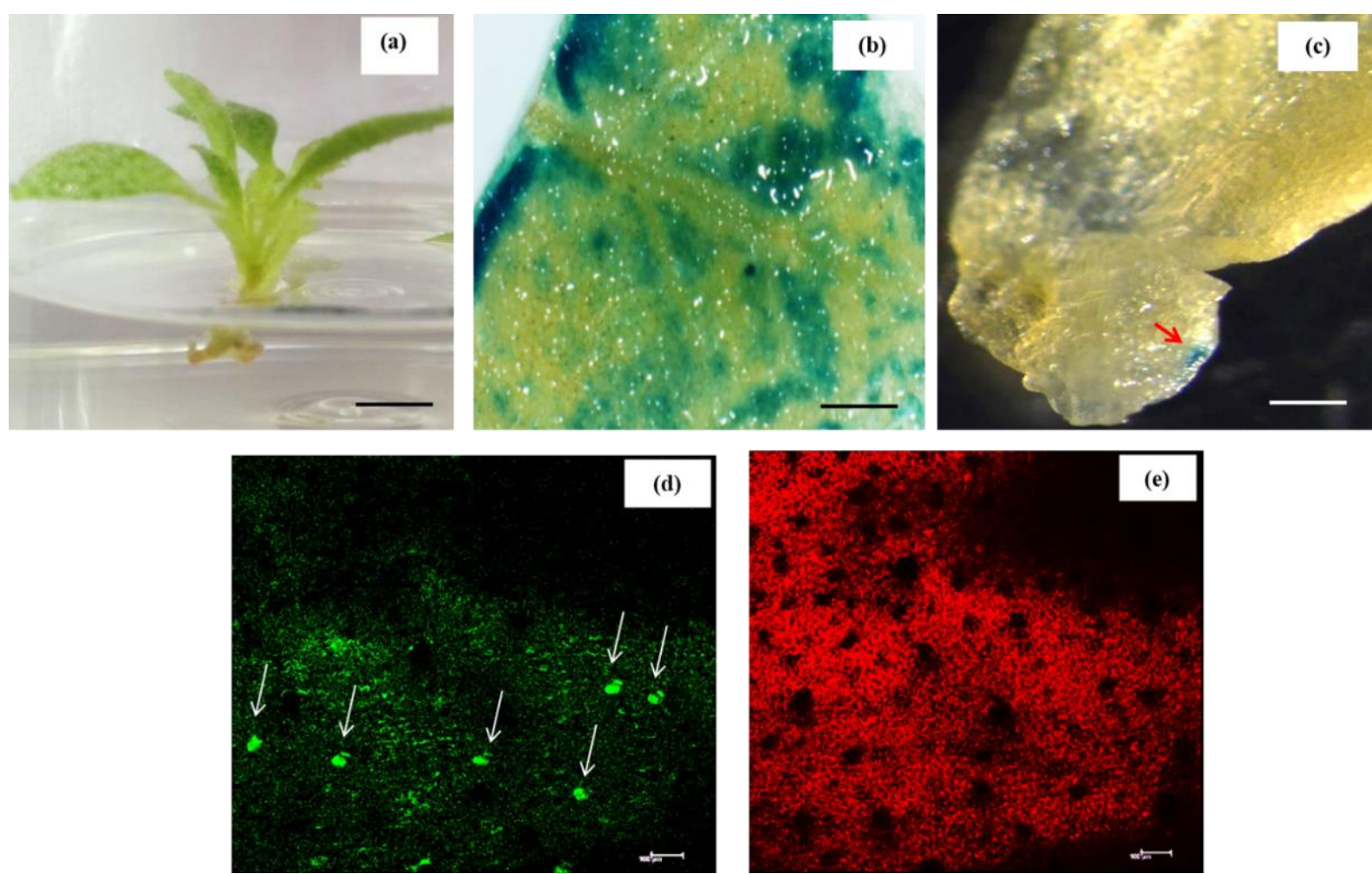

Figure 3. Transient analysis of $\mathrm{T}_{0}$ putative transformed shoots (10-week-old). (a) Regenerated hygromycin-resistant shoots on the selection medium; (b) GUS histochemical assay of expanded pCAMBIA 1304 putative transformed shoots; (c) GUS histochemical assay of expanded pTP60 putative transformed shoots, red arrow indicates an intense GUS

blue colouration; (d) Visualisation of expanded putative transformed shoots with pTP60 construct under a confocal laser scanning microscope (40X-oil immersion objective lens); (e)

Detection of red background colour signal on the same putative transformed of the expanded shoots as in (d) within untransformed region under UV. White arrows indicate the GFP signal. Bar $=0.5 \mathrm{~cm}(\mathrm{a}, \mathrm{b}, \mathrm{c})$ and $100 \mu \mathrm{m}(\mathrm{c}, \mathrm{d})$.

\subsection{PCR amplification}

To confirm the presence of the transgene in the $\mathrm{T}_{0}$ putative transformed shoots, 10-week-old regenerated shoots were analysed by PCR. Detection of about $914 \mathrm{bp}$ and $750 \mathrm{bp}$ of amplified fragments in the putatively transformed shoots confirmed the presence of TP60 (Figure 4a) and $m g f p 5$ (Figure 4b) genes, respectively. The expectation of the green fluorescence signal observed on the expanded putative transformed leaves correlated with the presence of $m g f p 5$. No amplification was detected in the genomic DNA of wild-type regenerated control plants.

All PCR-positive $\mathrm{T}_{0}$ plantlets were acclimatised in BSL2 compliant transgenic greenhouse, University of Malaya, Malaysia. The stable integration of heritable hptII gene in $\mathrm{T}_{1}$ tobacco plant genome was confirmed by PCR using the specific primer, HPT1, whereas, target gene specific primer (1304-sk) was used to confirm the stable integration of TP60 gene in $\mathrm{T}_{1}$ progenies. About $559 \mathrm{bp}$ and $914 \mathrm{bp}$ amplified fragments were detected using 
both HPT1 and 1304-sk primers, respectively, on hygromycin-resistant $T_{1}$ seedlings, including representative seedlings from lines FV3, FV12, FV16, and FV17 (Figure 4c and Figure 4d). This has confirmed the presence of transgene, which was stably inherited in the $T_{1}$ generation. Antibiotic-resistance selection marker gene located on the left border of $\mathrm{Ti}$ plasmid was used to ensure that truncation will not occur in the $T_{1}$ generation. It has been documented that the left border of $\mathrm{T}$ DNA was not inherited in subsequent generation after $\mathrm{T}_{0}$ (Kemski et al., 2013).

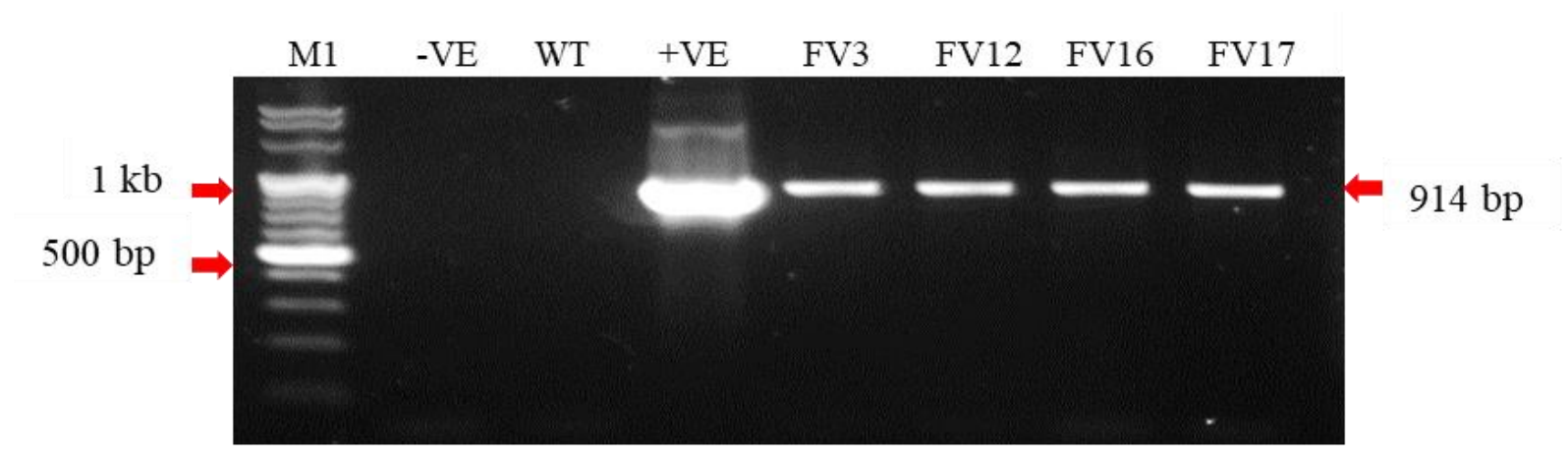

(a)

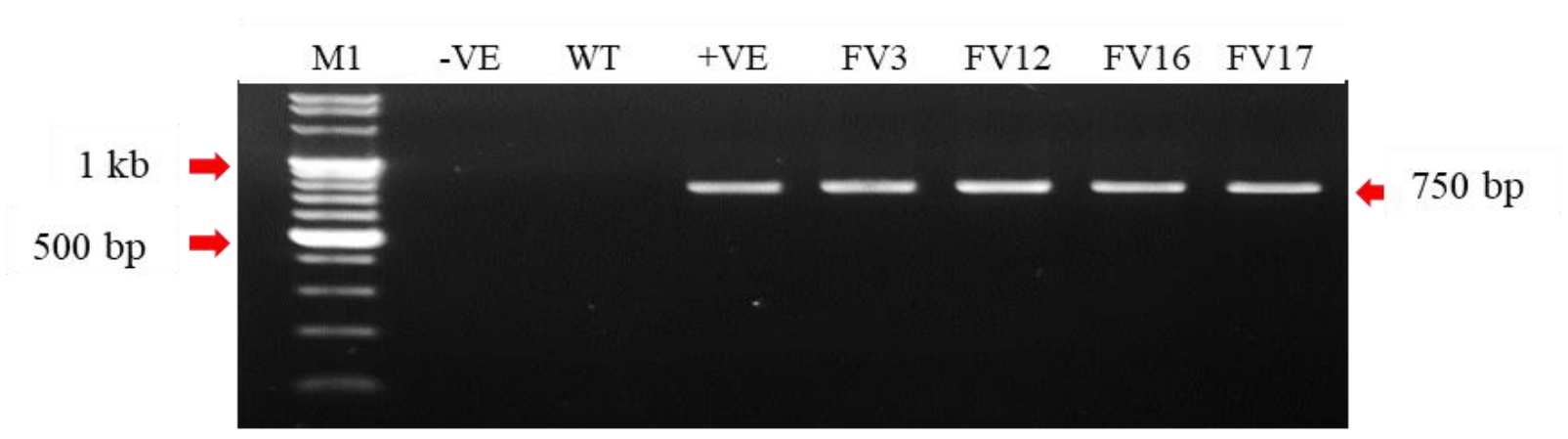

(b)

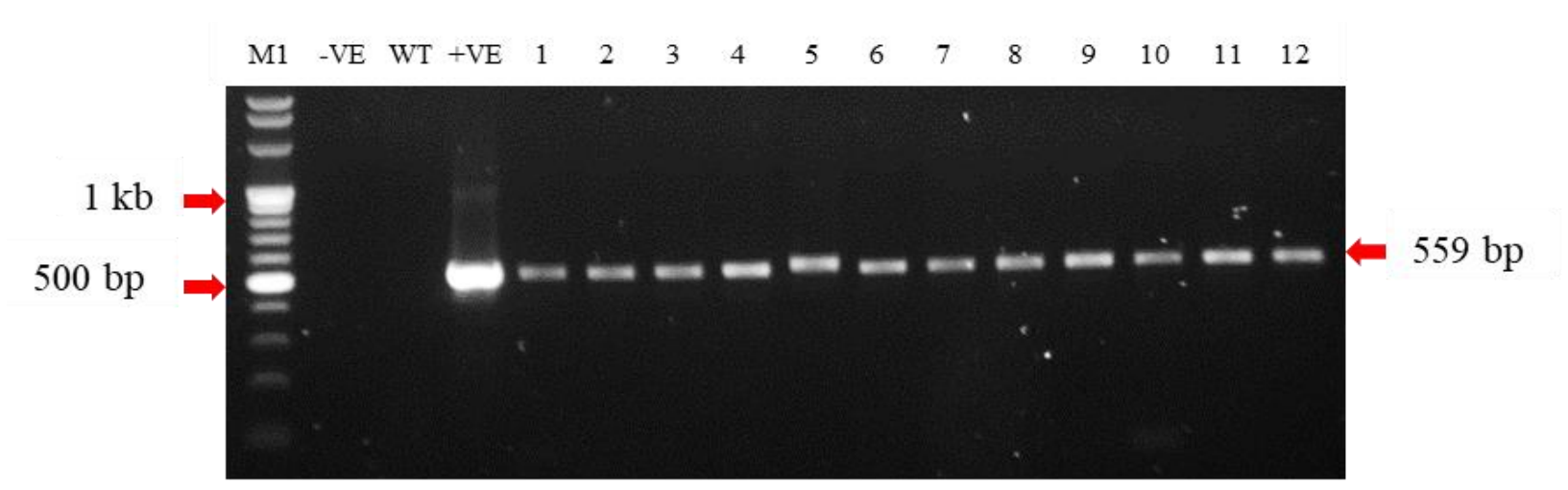

(c) 


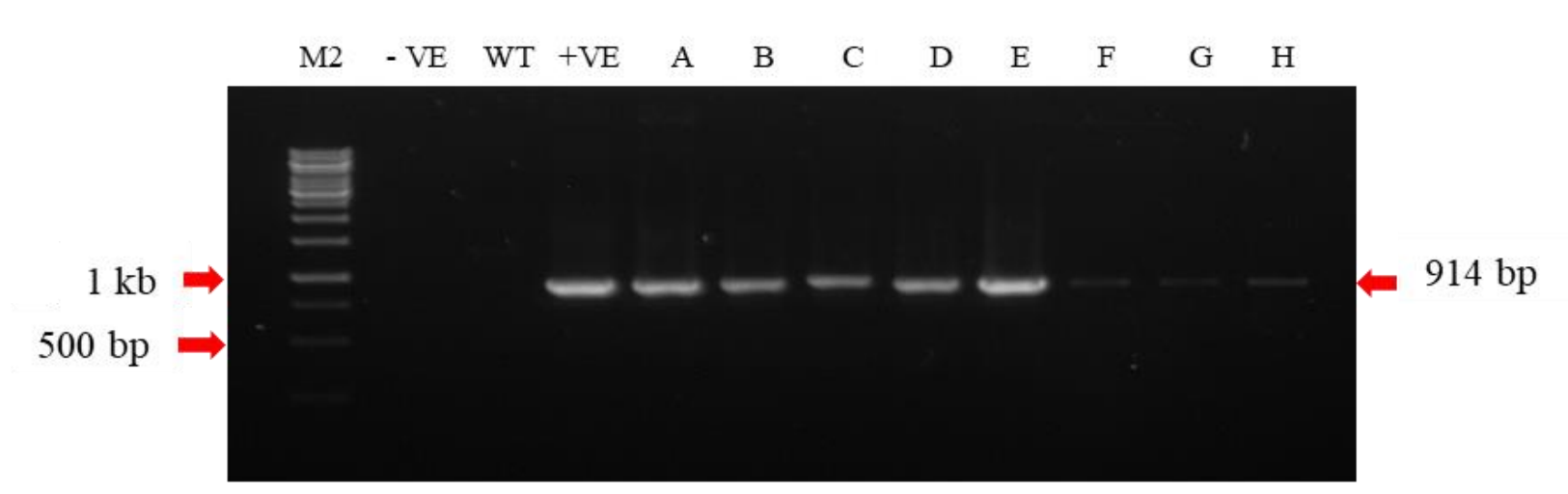

(d)

Figure 4. PCR screening of $\mathrm{T}_{0}$ and $\mathrm{T}_{1}$ tobacco plantlets and seedlings using specific target gene primers, (a) PCR amplification of $\mathrm{T}_{0}$ tobacco plantlets using 1304-sk, (b) PCR amplification of $\mathrm{T}_{0}$ tobacco plantlets using GFP primers (c) PCR screening of 10 week-old of $\mathrm{T}_{1}$ tobacco seedlings using HPT1 and (d) PCR screening of 10 week-old of $\mathrm{T}_{1}$ tobacco seedlings using 1304-sk primers. Lanes M1 and M2: Perfect ${ }^{\mathrm{TM}} 100$ bp DNA ladder and Perfect Plus 1 kb DNA ladder (Eur ${ }_{\mathrm{x}}$, Poland), respectively; -VE: negative control; WT: wild-type tobacco plantlet; +VE: positive plasmid control; FV3, FV12, FV16, and FV17: representatives of $\mathrm{T}_{0}$ tobacco plantlets from different transgenic lines; 1-12 and A-H: representatives of $\mathrm{T}_{1}$ tobacco seedlings from different transgenic lines.

\subsection{Phenotypic examination and segregation pattern of $T_{1}$ seedlings}

The percentage of germination and phenotypic changes in acclimatised $\mathrm{T}_{1}$ transgenic tobacco lines was assessed, and the results are tabulated in Table $2 . \mathrm{T}_{1}$ seeds from each representative line (approximately 100-200 seeds per line) were germinated on the selection media.

The percentage of germination was recorded after seven days. The results showed that wild-type tobacco seeds produced the highest percentage of germination $(95 \pm 2.9 \%)$ compared to other transgenic lines. Among all selected transgenic lines, the highest percentage of germination was recorded in FV17 (90\%), followed by FV12 (86\%), FV3 (82\%), and FV16 (76\%). The non- transformant seedlings germinated on the selection media resulted in necrosis and/or showed moderate growth with green-pale colour (Figure 5e). The non-transformed seedlings were then discarded due to their abnormal growth appearance. However, some transgenic seedlings showed delayed germination (more than 14 days), causing the percentage of germination not assessed. The delayed germination might be due to selective pressure on transgenic seeds to adapt to the antibiotic-containing media. As previously reported by Eluk et al. (2016), the introduction of antibiotics, such as enrofloxacin, oxytetracycline, penicillin, and tylosin, in the culture media has delayed germination in the seeds of Glycine max, Helianthus annus, Sorghum bicolor, Triticum aestivum, and Zea mays, showing a phytotoxic action on crop growth, in contrast to our $\mathrm{T}_{1}$ transgenic tobacco seeds. 
Phenotypic characteristics, such as percentage of germination and stem height, were not significantly different $(p<0.05)$ between the transgenic lines and wild-type tobacco plants, suggesting that this antiToxoplasma protein did not interfere the growth development and physiology of the tobacco plant itself. These characteristics may be useful for biopharming production (Ahmad et al., 2012b). We then observed the flowering time for the transgenic and wild-type lines by recording the shortest and a mean number of flowering periods. We found that the transgenic line FV16 exhibited the shortest flowering period (26 days), whereas the wild-type tobacco plants displayed longer flowering period (65 days) compared to the transgenic lines. In general, the flowering period for TP60transformants and wild-type was not significantly different $(p<0.05)$, as flowering was observed at $62 \pm 2$ and $65 \pm$ 6 days, respectively. The introduction of this recombinant protein gene into the tobacco plants has led to early flowering compared to wild-type. Different flowering days, as shown in transgenic lines, might be due to the different positions of the insert into the tobacco host genome. This nonphotoperiodic flowering, a facultative response to day length, is probably due to stress (Takeno, 2012). Flowering is a vital life-history trait for plants to ensure seed production required for survival. Plants may alter its flowering time as one of the evolutionary strategies to maximise the chances of reproduction under diverse stress conditions, such as pathogen infection and environmental stress (Kazan \& Lyons, 2016).

The number of transgene insertions was identified by the segregation pattern analysis of $\mathrm{T}_{1}$ seedlings based on $h p t \mathrm{II}$ gene activity using Chi-square analysis (Table 3 ). The inheritance pattern of three independent lines, namely FV3, FV12, and FV16, followed Mendelian inheritance by showing a 3:1 ratio (hygromycinresistance:hygromycin-sensitive). This result indicated that $h p t \mathrm{II}$ genes were integrated into a single locus in these transgenic lines and stably inherited to $\mathrm{T}_{1}$ generation (Datta et al., 2001; Chen, 2011).

On the other hand, FV17 did not follow the segregation pattern of 3:1 Mendelian inheritance. This might be due to the integration of hptII gene, which was not within a single locus in this transgenic line or into the unstable transgenic loci, which may reflect complex rearrangement of the integrated genes (Tizaoui \& Kchouk, 2012).

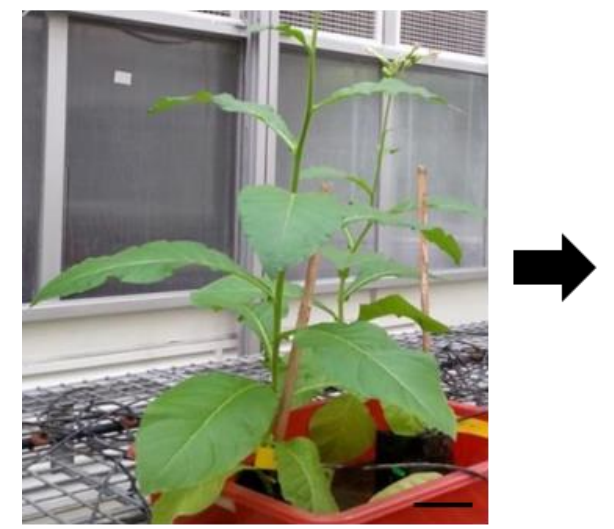

(a)

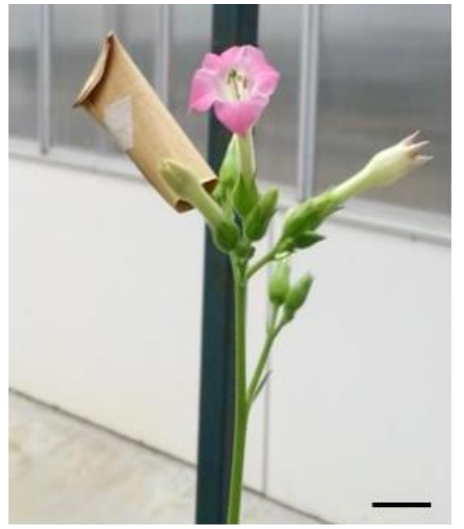

(b)

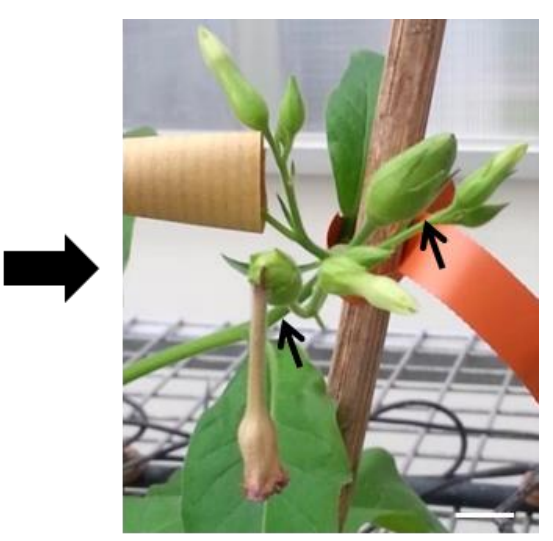

(c) 


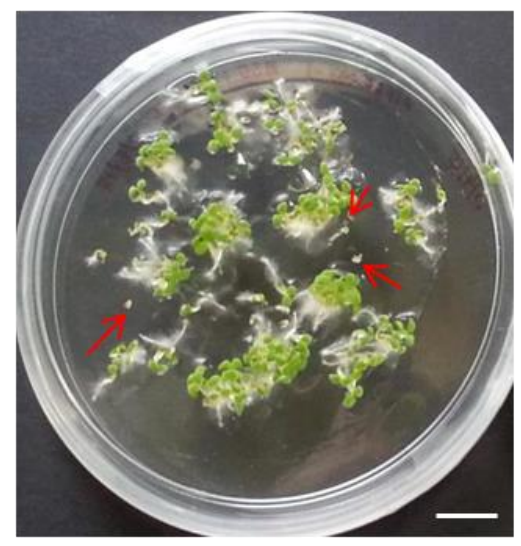

(e)

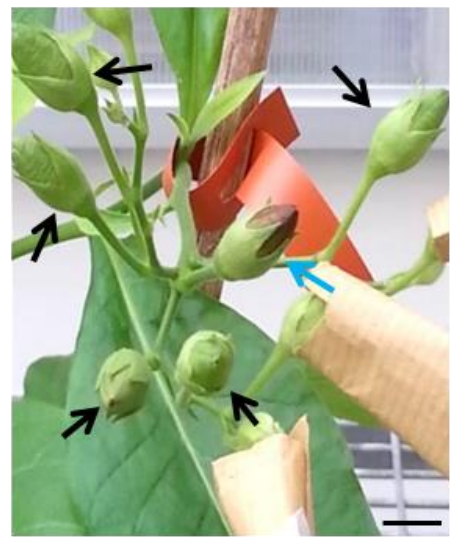

(d)

Figure 5. The growth stages of transgenic $N$. tabacum cv. SR1 within 3 months of acclimatisation. (a) 6-week-old of acclimatised transgenic tobacco plants; (b) 8-week-old of acclimatised transgenic tobacco plants; (c) Formation of seed pods (black arrows), 4-6 days of post-pollination; (d) Drying seed pods after 1 month of maturity (blue arrow).

Ready for the collection of $\mathrm{T}_{1}$ seeds after the browning of sepals and stem; (e) Approximately 2 -week-old of germinated $\mathrm{T}_{1}$ seeds on selection media. Red arrows indicate the non-transformant of $\mathrm{T}_{1}$ seedlings germinated on selection media with green-pale colour and abnormal appearance. $\mathrm{Bar}=1 \mathrm{~cm}$.

Table 2. The percentage of germination (after 7 days of germination), stem height (20 days of post-acclimatisation) and flowering period of $T_{1}$ independent transgenic lines. Same parameters were recorded for wild-type plants as control.

Line

Percentage of germination $(\%)$
Stem height

(cm)
Flowering period (day)

Wild-type

$95 \pm 2.9^{\mathrm{a}}$

$8.97 \pm 1.5^{\mathrm{c}}$

FV3

$82 \pm 6.5^{\mathrm{a}, \mathrm{b}}$

$9.2 \pm 1.4^{\mathrm{c}}$

FV12

$86 \pm 2.1^{\mathrm{a}, \mathrm{b}}$

$10.2 \pm 2.1^{\mathrm{c}}$

FV16

$76 \pm 5.2^{\mathrm{b}}$

$12.80 \pm 1.3^{\mathrm{c}}$

FV17

$90 \pm 5.3^{\mathrm{a}, \mathrm{b}}$

$13.57 \pm 7.0^{\mathrm{c}}$ 
The results represent the mean \pm standard error of the mean (SEM) of three replicated experiments. Different letters indicate significant difference between samples at $p<0.05$.

Table 3. Segregation of hptII gene in the $\mathrm{T}_{1}$ tobacco plants

\begin{tabular}{|c|c|c|c|c|c|}
\hline \multirow{2}{*}{$\begin{array}{l}\text { Transgenic lines } \\
\text { (from } \mathbf{T}_{0} \text { ) }\end{array}$} & \multirow{2}{*}{$\begin{array}{c}\text { Total number } \\
\text { of } \mathbf{T}_{1} \\
\text { germinated } \\
\text { seeds }\end{array}$} & \multicolumn{4}{|c|}{ Segregation Pattern } \\
\hline & & $\operatorname{hptII^{\mathrm {R}}}$ & $h p t I I^{\mathrm{S}}$ & Ratio & $\chi^{2}$ \\
\hline FV3 & 133 & 106 & 27 & $3: 1$ & 1.566 \\
\hline FV12 & 129 & 90 & 39 & $3: 1$ & 1.884 \\
\hline FV16 & 139 & 105 & 34 & $3: 1$ & 0.022 \\
\hline FV17 & 129 & 71 & 58 & - & - \\
\hline
\end{tabular}

Each $\mathrm{T}_{0}$ line represents an independent event of transformation. Total number of $\mathrm{T}_{1}$ germinated seeds: Number of seeds germinated on the selection media from the corresponding transgenic line of $\mathrm{T}_{0}$. hpt $\mathrm{II}^{\mathrm{R}}$ and $h p t \mathrm{II}^{\mathrm{S}}$ represent the resistant (germinated) and susceptible (nongerminated) seeds on selection mediacontaining hygromycin respectively. Three lines (FV3, FV12, and FV16) showed a ratio of 3:1 (hpt $\mathrm{II}^{\mathrm{R}}$ : hpt $\left.\mathrm{II}^{-}\right)$. Lines which were not fit the ratio of 3:1 were represented by “-”.

\subsection{Gene expression and quantification of recombinant anti- Toxoplasma gene}

In this study, the expression profiles of the TP60 gene between three selected individuals of each $T_{1}$ transgenic tobacco line were assessed (Figure 6). The third main stem leaves of tobacco plants were used for gene expression analysis. Our quantitative PCR (RT-qPCR) analysis showed that the transcript of TP60 transgene was detected in all tested transgenic plant samples. A representative of each line, FV3-11 (Figure 6a), FV12-6 (Figure 6b), FV16-10 (Figure 6c), and FV17-7 (Figure 6d) that showed the highest in TP60 expression in comparison to the other two individual samples were subjected to Western blot analysis. Based on the representative individuals of each line, FV12-6 showed the highest TP60 expression at 7-fold change, followed by FV16-10 at 2-fold change, and FV17-7 at 1-fold change compared to FV3-11 (Figure 7). The differences in the TP60 transgene expression level between transgenic lines might be due to the position effect during transformation event. 
(a)

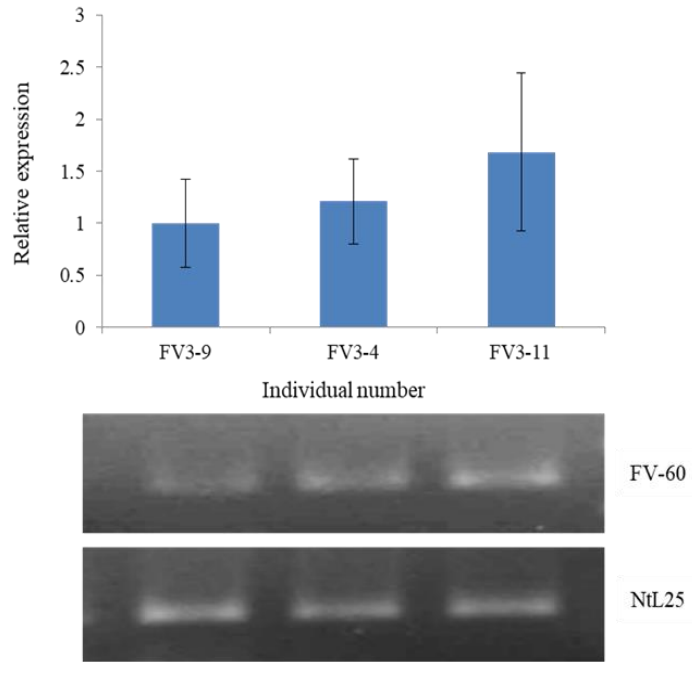

(c)

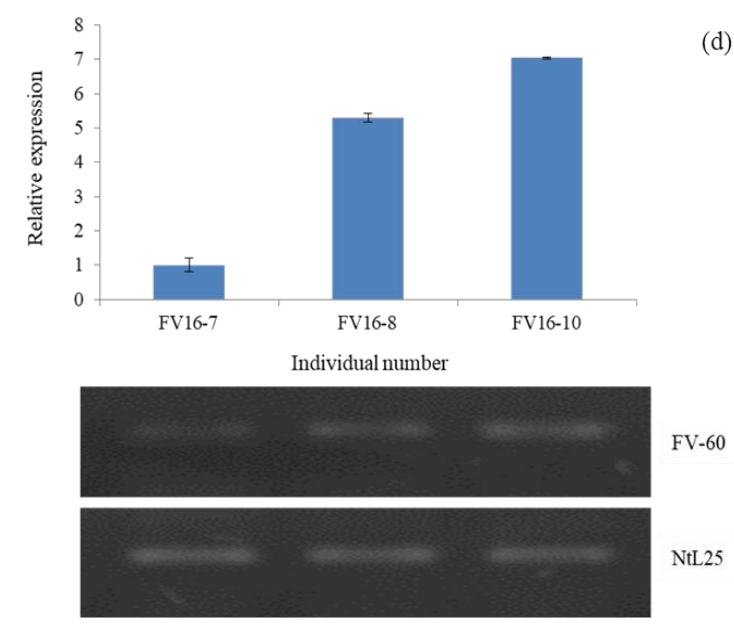

(b)
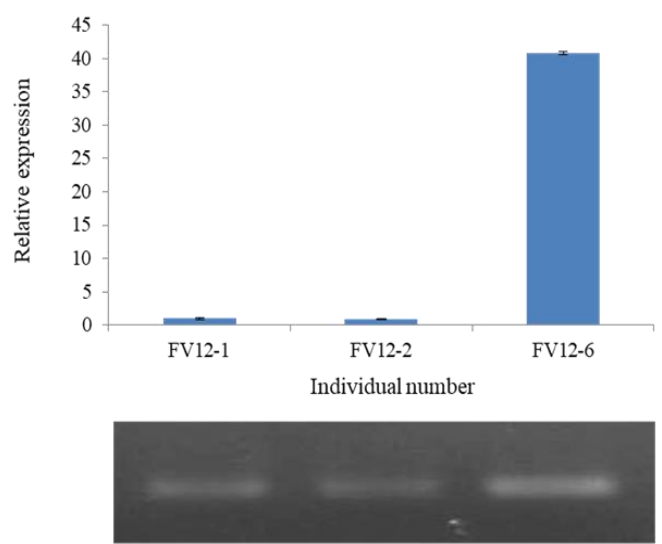

FV-60

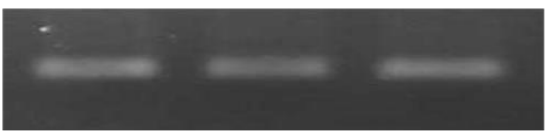

NtL25

Figure 6. Quantitative PCR (RT-qPCR) and semi-quantitative PCR (RT-PCR) analysis of the transgene expression level for (a) FV3; (b) FV12; (c) FV16; and (d) FV17. Semiquantitative PCR showed bands at the expected size of $149 \mathrm{bp}$ and $139 \mathrm{bp}$ of the target (FV60 primers) and internal reference gene (NtL25 primer), respectively. Bars represent the standard errors of three technical replicates. Relative expression on $Y$ axis represents TP60 transcript levels to individual of FV3-9, FV12-2, FV16-7, and FV17-3 for transgenic lines FV3, FV12, FV16, and FV17, respectively. 

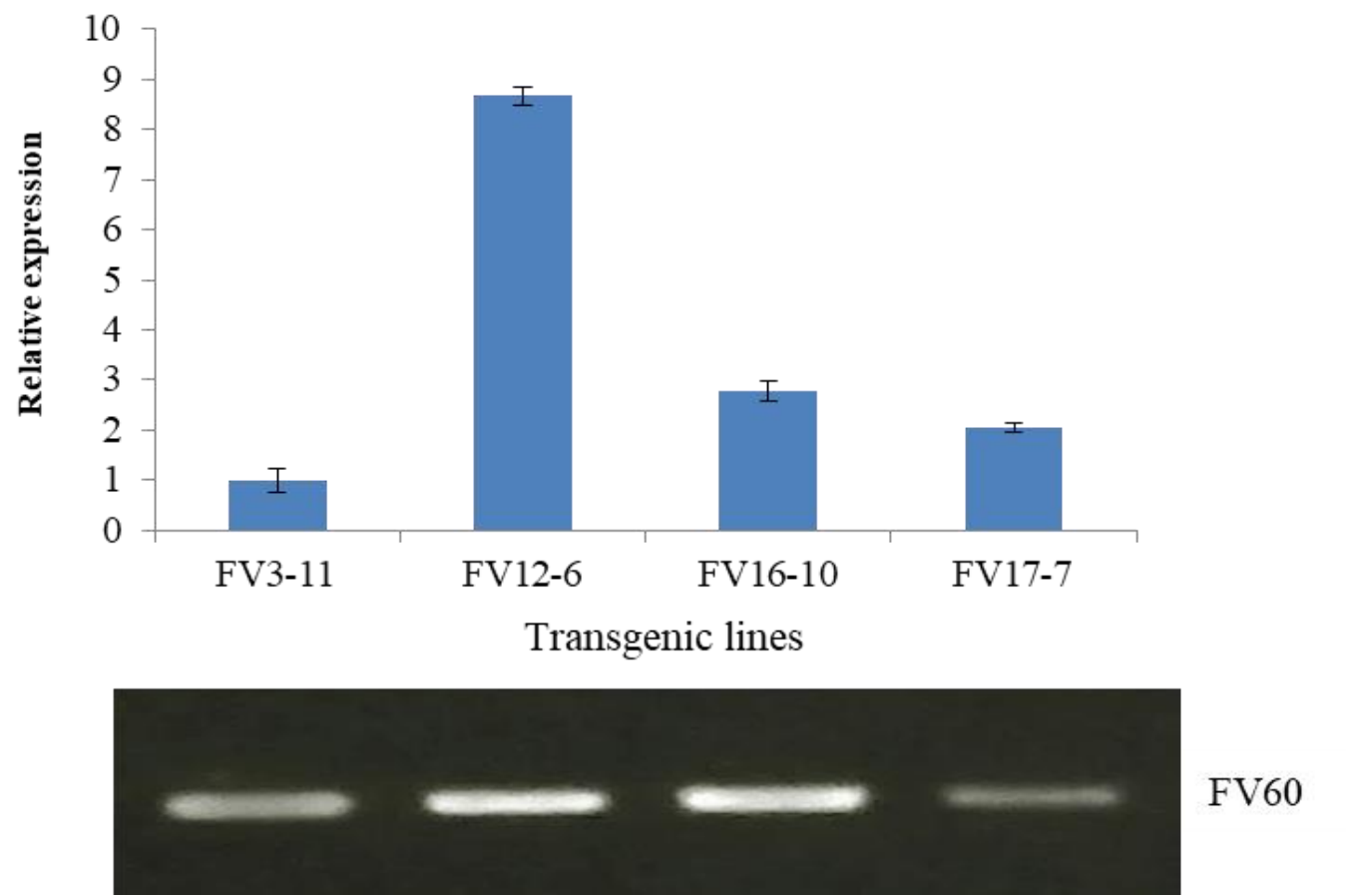

Figure 7. Quantitative PCR (RT-qPCR) and semi-quantitative PCR (RT-PCR) analysis of expression level of TP60 for FV3, FV12, FV16, and FV17. Semi-quantitative PCR showed a single band at the expected size of $149 \mathrm{bp}$ for the target gene (FV-60 primers). Bars represent

the standard errors of three technical replicates. Relative expression on $Y$ axis represents TP60 transcript for FV3, FV12, FV16, and FV17 relative to FV3-11.

\subsection{Recombinant anti-Toxoplasma protein expression in tobacco plants}

SDS-PAGE and Western blot analyses were performed to confirm the stable production of TP60 protein in the $\mathrm{T}_{1}$ generation. Total soluble dImer protein showed a clear band at the predicted size of $\sim 54 \mathrm{kDa}$ (Figure 8a). An intense band was detected in the wild-type control sample, probably due to the presence of other native protein with a similar size as the recombinant protein. The purified recombinant proteins showed a clear band at the sizes of $\sim 60 \mathrm{kDa}$ and $\sim 54 \mathrm{kDa}$ (Figure $8 \mathrm{~b}$ ). The presence of unspecific band with the size of $\sim 60 \mathrm{kDa}$ might be due to the interference of eluted monoclonal E-epitope tag $\mathrm{IgG}$ antibody that covalently bound to the bead together with our target recombinant protein during the elution step.

The detection of anti-Toxoplasma TP60 protein using anti-E tag fused protein (Figure 8c) confirmed the expression of the targeted protein at the size of $\sim 54 \mathrm{kDa}$ instead of $\sim 27 \mathrm{kDa}$ ( $\mathrm{scFv}$ protein size) without the interference of unspecific band at $\sim 60 \mathrm{kDa}$. The dimeric formation of TP60 protein might be due to serine residue present in the linker peptide

(GGSSRSS), involving dimer formation of the disulphide band under reducing conditions (Schouten et al., 2002). Dobhal et al. (2013) reported that the dimerisation of recombinant protein produced from $N$. tabacum cv. Xanthi was due to cysteine residue present in the linker 
peptide of the recombinant protein. The small size of the linker peptide $(<15$ amino acids) in $\mathrm{scFv}$ tends to form dimers (Yusakul et al., 2015). Although TP60 protein has been previously expressed at $\sim 27 \mathrm{kDa}$ (Lim et al., 2012), we speculate that the dimeric formation of TP60 protein in this study might be due to other factors, such as high ionic strength and $\mathrm{pH}$ below than 7.5 during the preparation of samples (Katja et al., 1998). As demonstrated by Giersberg et al. (2010), dimerised anti${ }^{\mathrm{Nb}} \mathrm{TNF}-\mathrm{V}_{\mathrm{H}} \mathrm{H}_{\mathrm{CK}}$ proteins produced from Nicotiana benthamiana were able to block the TNF $\alpha$-activity more effectively than monomeric anti- ${ }^{\mathrm{Ec}} \mathrm{TNF}-\mathrm{V}_{\mathrm{H}} \mathrm{H}_{\mathrm{CK}}$ protein produced in E. coli. Ahmad et al. (2012) demonstrated that dimer proteins had better avidity and stability compared to monovalent $\mathrm{scFv}$. This may increase the yield of protein production. Hence, we speculate that the dimeric formation of TP60 protein in this study could potentially increase the effectiveness and inhibition toward the $T$. gondii tachyzoite antigen. No band was observed in the wildtype tobacco plants (Figure 8c).
Transgenic line FV12-6 showed the highest protein accumulation $(1.67 \mu \mathrm{g} / \mathrm{g})$ compared to the rest of the samples, which correlated with the gene transcript at mRNA level (Table 4). The predicted protein size was confirmed using http://web.expasy.org/translate/onlinesoft ware (Artimo et al., 2012). The TP60 protein yield was calculated by dividing the amount of purified TP60 protein over the total soluble protein (TSP) identified in the plant leaves using Bradford's assay. The purified protein yield ranged from $0.18 \%$ to $0.52 \%$ (Table 4 ). The highest amount of $\mathrm{scFv}$ recombinant protein $(0.52 \%$ out of total soluble protein $)$ obtained from FV12-6 was almost the same yield as the study conducted by Wang et al. (2015) on the production of acidic fibroblast growth factor $\mathrm{scFv}$ using $N$. benthamiana. However, MakvandiNejad et al. (2005) demonstrated that about $41.7 \mu \mathrm{g} / \mathrm{g}$ of dimeric scFv antibody against Salmonella enterica Serotype Parathyphi B could be produced in N. tabacum. The difference of recombinant protein yield might be due to the different methods of purification and quantification.

(a)

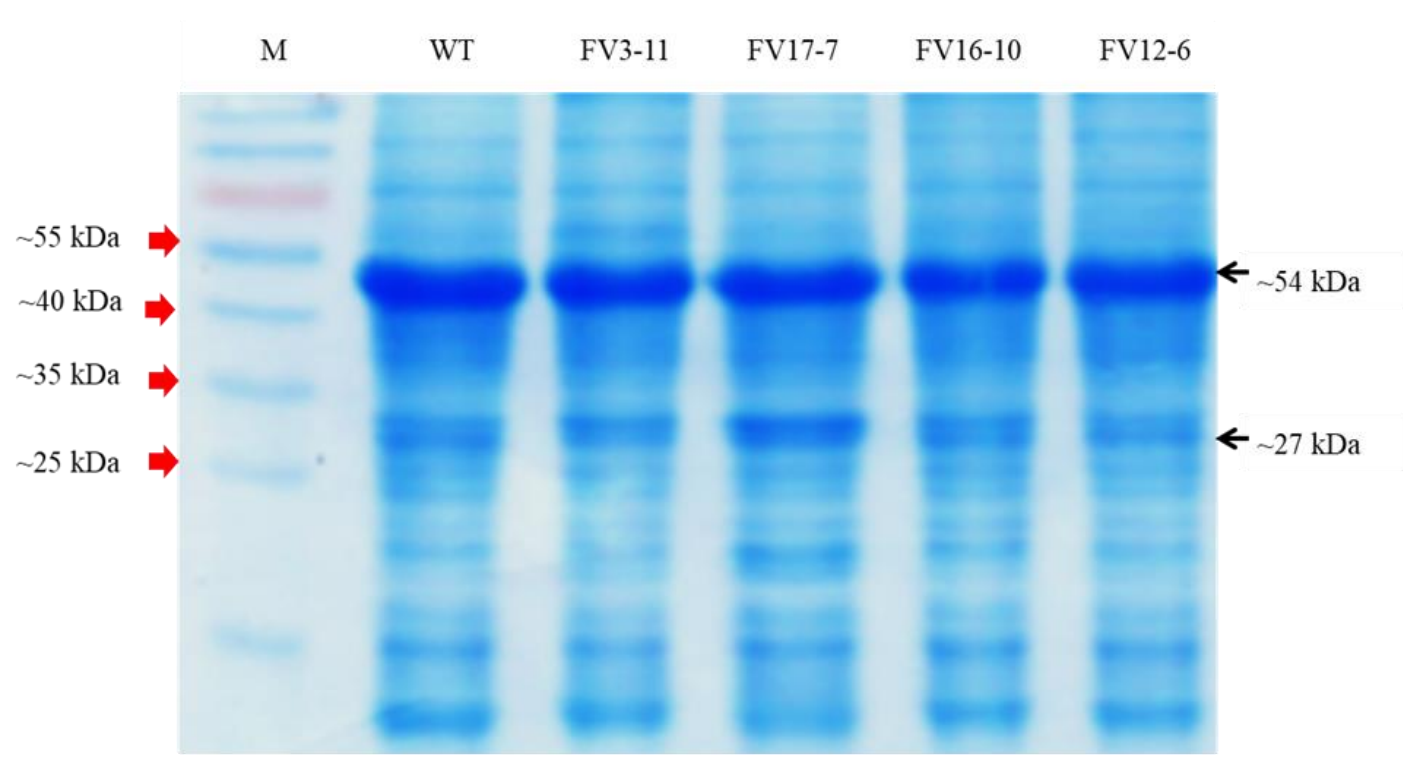


(b)

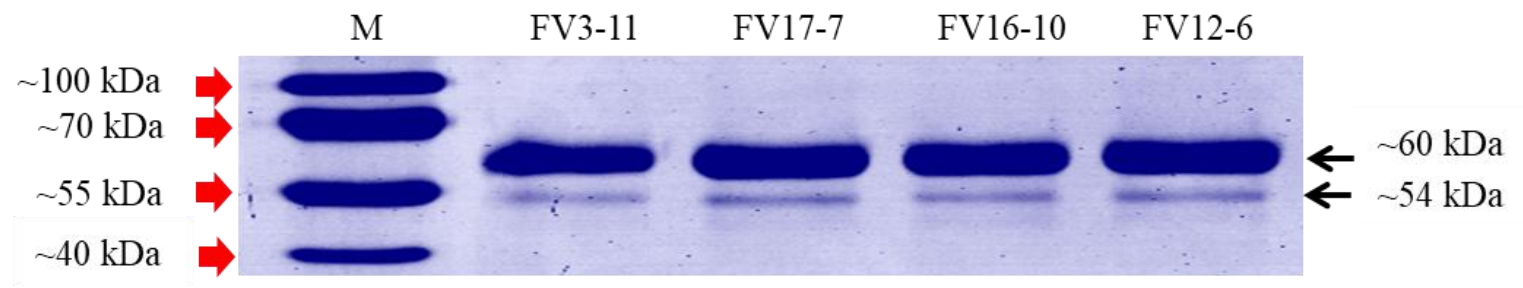

(c)

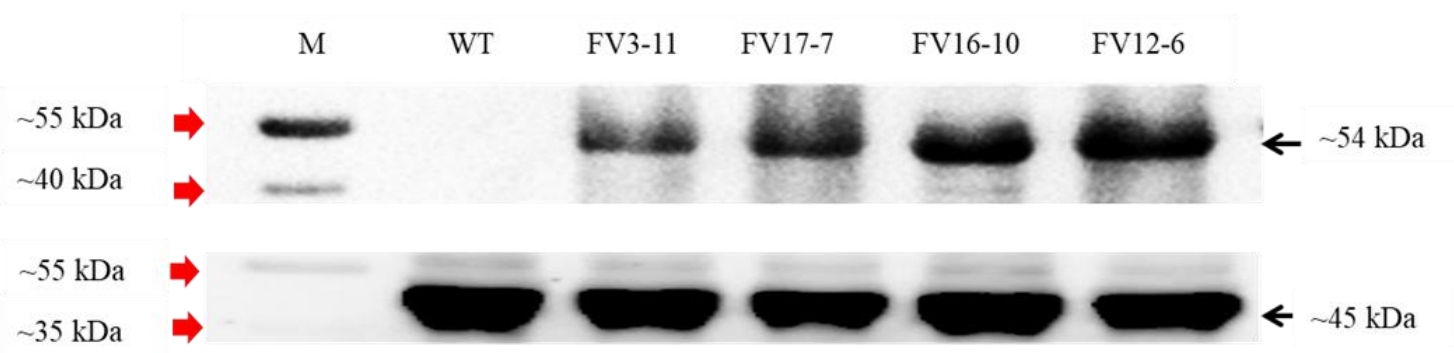

Figure 8. Stable expression of purified TP60 protein in $\mathrm{T}_{1}$ plant of Nicotiana tabacum $\mathrm{cv}$. SR1. (a) Total soluble protein extracted from wild-type and transgenic lines of $\mathrm{T}_{1}$ tobacco leaves; (b) SDS-PAGE of purified recombinant protein using DyNabeads ${ }^{\mathrm{TM}}$; (c) Detection of TP60 recombinant protein fused with E-epitope tag in FV3-11, FV17-7, FV16-10 and FV126 lines at $54 \mathrm{kDa}$ except for wild-type control sample following actin-11 as loading control at the predicted size of $45 \mathrm{kDa}$; (M) PageRuler ${ }^{\mathrm{TM}}$ Pre-stained Protein Ladder, 10-180 kDa (except for loading control). Marker used for loading control was PageRuler ${ }^{\mathrm{TM}}$ Plus Prestained Protein Ladder 10-250 kDa (Thermo Scientific, USA).

Table 4. Determination of recombinant anti-Toxoplasma scFv protein (TP60) expressed in the $\mathrm{T}_{1}$ transgenic plants through Bradford's quantification after 40-days of acclimatisation.

Transgenic

lines
Maximum antibody accumulation level

\begin{tabular}{lcc} 
FV3-11 & 1.16 & 0.18 \\
FV12-6 & 1.67 & 0.52 \\
FV16-10 & 1.30 & 0.25 \\
FV17-7 & 1.14 & 0.18 \\
\hline
\end{tabular}


Our study demonstrated that the production of recombinant antiToxoplasma protein in plants is feasible and economical without the need for laborious downstream processes, such as chemical refolding or purification against pathogen contamination of the end protein products. Thereby, the problematic and devastating procedures to obtain the biologically active protein product can be avoided. This technology could also be exploited for the production of pharmaceutically important diagnostic antibodies for the healthcare sector. This will also open up new sectors such as agrochemical and pharmaceuticals industries. Further work will involve a strategy to enhance the production of recombinant protein in terms of yield, protein stability, and functionality.

\section{ACKNOWLEDGEMENTS}

This work was supported by the Ministry of Higher Education, High Impact $\mathrm{R}$ e $\mathrm{s}$ e a r c h $\mathrm{P}$ r o g r a m m e (UM.C/625/1/HIR/MOHE/SCI/18), Postgraduate Research Grant of University of Malaya (PG204-2016A) and Research University (RU006-2017 and ST003-2018) grants. We thank Dr. Sherene Lim Swee Yin, Novartis Pharmaceuticals, Petaling Jaya, Malaysia for providing the antiToxoplasma ( $\mathrm{scFv}$ ) gene. Special gratitude to Plant Biotechnology Research Laboratory members, Dr. Teo Chee How and HIR Interactome laboratory members, and Prof. Dr. Zulqarnain bin Mohamed group members for their valuable guidance.

\section{AUTHOR CONTRIBUTIONS}

RYO, NZK, and BCT conceived the idea, designed the experiments and edited the manuscript. FIR conducted the experiments. PSG constructed the plasmid. FIR and BCT wrote the manuscript. NAR edited the manuscript. All authors read and approved the manuscript.

\section{CONFLICT OF INTEREST}

The authors declare that they have no competing interests.

\section{REFERENCES}

Ahmad ZA., Yeap SK., Ali AM., Ho WY., Alitheen NBM. \& Hamid, M. (2012a). scFv antibody: principles and clinical application. Clinical and Development Immunology 2012: 115.

Ahmad P., Ashraf M., Younis M., Hu X., Kumar A., Akram NA. \& Al-Qurany, F. (2012b). Role of transgenic plants in agriculture and biopharming. Biotechnology Advances 30(3): 524540.

Amaro MO., Xisto MF., Dias AS., Versiani AF., Cardoso SA., Otoni WC., da Silva CC. \& De Paula, SO. (2015). Antigen production using heterologous expression of dengue virus-2 non-structural protein 1 (NS1) in Nicotiana tabacum (Havana) for immunodiagnostic purposes. Plant Cell Reports 34(6): 919-928.

Artimo P., Jonnalagedda M., Arnold K., Baratin D., Csardi G., de Castro E., Duvaud S., Flegel V., Fortier A., Gasteiger E., Grosdidier A., Hernandez C., Ioannidis V., Kuznetsov D., Liechti R., Moretti S., Mostaguir K., Redaschi N., Rossier G., 
Xenarios I. \& Stockinger, H. (2012). ExPASy: SIB bioinformatics resource portal. Nucleic Acids Research 40(W1): W597-W603.

Bradford, MM. (1976). A rapid and sensitive method for the quantification of microgram quantities of protein utilizing the principle of protein-dye binding. Analytical Biochemistry 7(72): 248254.

Burrells A., Benavides J., Cantón G., Garcia JL., Bartley PM., Nath M., Thomson J., Chianini F., Innes EA. \& Katzer, F. (2015). Vaccination of pigs with the S48 strain of Toxoplasma gondii-safer meat for human consumption. Veterinary Research 46(47).

Bustin SA., Benes V., Garson JA., Hellemans J., Hugget J., Kubista M., Mueller R., Nolan T., Pfaffl MW., Shipley GL., Vandesompele J. \& Wittwer, CT. (2009). The MIQE guidelines: minimum information for publication of quantitative real-time PCR experiments. Clinical Chemistry 55(4): 611-622.

Buxton D. \& Innes, EA. (1995). A commercial vaccine for ovine toxoplasmosis. Parasitology 110: S11-S116.

Buxton D. \& Rodger, S.M. (2008). Toxoplasmosis and neosporosis, pp. 112-118, New Jersey, USA: WileyBlackwell, Hoboken.

Cérutti M. \& Golay, J. (2012). Lepidopteran cells, an alternative for the production of recombinant antibodies? mAbs 4(3): 294-309.
Chaudhry SA., Gad N. \& Koren, G. (2014). Toxoplasmosis and pregnancy. Canadian family physician. Medecin de Famille Canadien 60(4): 334-336.

Chen GQ. (2011). Effective reduction of chimeric tissue in transgenics for the stable genetic transformation of Lesquerella fendleri. HortScience 46(1): 86-90.

Chen Q. (2015). Plant-made vaccines against West Nile virus are potent, safe, and economically feasible. Biotechnology Journal 10(5): 671-680.

Cummings JF., Guerrero ML., Moon JE., Waterman P., Nielsen RK., Jefferson S., Gross FL., Hancock K., Katz JM. \& Yusibov, V. (2014). Safety and immunogenicity of a plant-produced recombinant monomer hemagglutinin-based influenza vaccine described from influenza $A$ (H1N1) pdm09 virus: A Phase 1 doseescalation study in healthy adults. Vaccines 32(19): 2251-2259.

Datta K., Tu J., Oliva N., Ona I., Velazhahan R., Mew TW., Muthukrishnan S. \& Datta, SK. (2001). Enhanced resistance to sheath blight by constitutive expression of infection-related rice chitinase in transgenic elite indica rice cultivars. Plant Science 160(3): 405-414.

Dent M., Hurtado J., Paul AM., Sun H., Lai H., Yang M., Esqueda A., Bai F., Steinkellner H. \& Chen, Q. (2016). Plant-produced anti-dengue virus monoclonal antibodies exhibit reduced antibody-dependent enhancement of infection activity. Journal of General Virology 97(12): 3280-3290. 
Dobhal S., Chaudhary VK., Singh A., Pandey D., Kumar A. \& Agrawal, S. (2013). Expression of recombinant antibody (single chain antibody fragment) in transgenic plant Nicotiana tabacum cv. Xanthi. Molecular Biology Report 40(12): 7027-7037.

Elfahal AM., Elhassan AM., Hussien MO., Enan KA., Musa AB. \& El Hussein, AM. (2013). Seroprevalence of Toxoplasma gondii in Dairy Cattle with Reproductive Problems in Sudan. ISRN veterinary science 2013(895165).

Eluk D., Nagel OG., Zimmerman J., Molina MP. \& Althaus, RL. (2016). Effect of antibiotics on the germination and root elongation of argentine intensive crops. International Journal of Environmental Research 10(4): 471480.

Farajnia S., Ahmadzadeh V., Tanomand A., Veisi K., Khosroshahi SA. \& Rahbarnia, L. (2014). Development trends for generation of single-chain antibody fragments. Immunopharmacology and Immunotoxicology (36)5: 297-308.

Flego M., Frau A., Accardi L.,Mallano A., Ascione A., Gellini M., Fanunza E., Vella S., Bonito PD. \& Tramontano, E. (2019). Intracellular human antibody fragments recognizing the VP35 protein of Zaire Ebola filovirus inhibit the protein activity. BMC Biotechnology 19(64).

Flegr J., Prandota J., Sovičková M. \& Israili, ZH. (2014). Toxoplasmosis A Global Threat. Correlation of Latent Toxoplasmosis with Specific Disease
Burden in a Set of 88 Countries. PLOS ONE 9(3): e90203.

Foroutan M., Ghaffarifar F., Sharifi Z., Dalimi A. \& Jorjani, O. (2019). Rhoptry antigens as Toxoplasma gondii vaccine target. Clinical and Experimental Vaccine Research. 8(1): 4-26.

Giersberg M., Floss DM., Kipriyanov S., Conrad U. \& Scheller, J. (2010). Covalent dimerization of camelidae anti-human TNF-alpha single domain antibodies by the constant kappa light chain domain improves neutralizing activity. Biotechnology and Bioengineering 106(1): 161-166.

Go PS. (2013). Expression of antiToxoplasma scFv antibodies in plants. Dissertation, University of Malaya.

Goldman JJ., Hanna WW., Fleming G. \& Ozias-Akins, P. (2003). Fertile transgenic pearl millet [Pennisetum glaucum (L.) R. Br.] plants recovered through microprojectile bombardment and phosphinothricin selection of apical meristem-, inflorescence-, and immature embryo-derived embryogenic tissues. Plant Cell Reports 21: 482-486.

Innes EA., Bartley PM., Rocchi M., Benavidas-Silvan J., Burrells A., Hotchkiss E., Chianini F., Canton G. \& Katzer, F. (2011). Developing vaccines to control protozoan parasites in ruminants: dead or alive? Veterinary Parasitology 180(1-2): 155-163.

Jefferson RA., Kavanagh TA. \& Bevan, MW. (1987). GUS Fusions: $\beta$ glucuronidase as a sensitive and versatile gene marker in higher plants. EMBO Journal 6: 3901-3907. 
Kamaté K., Rodriguez-Llorente ID., Scholte M., Durand P., Ratet P., Kondorosi A. \& Trinh, TH. (2000). Transformation of floral organs with GFP in Medicago truncatula. Plant Cell Reports 19: 647-653.

Katja MA., Kristian MM. \& Andreas, P. (1998). Factors Influencing the Dimer to Monomer Transition of an Antibody Single-Chain Fv Fragment. Biochemistry 37(37): 12918-12926.

Kazan K. \& Lyons, R. (2016). The link between flowering time and stress tolerance. Journal of Experimental Botany 67(1): 47-60.

Kemski MM., Stevens B. \& Rappleye, CA. (2013). Spectrum of T-DNA integrations for insertional mutagenesis of Histoplasma capsulatum. Fungal Biology 117(1): 41-51.

Kim MY., Reljic R., Kilbourne J., Ceballos-Olvera I., Yang MS., Reyesdel Valle J. \& Maso, HS. (2015). Novel vaccination approach for dengue infection based on recombinant immune complex universal platform. Vaccine 33(15): 1830-1838.

Kurasawa JH., Shestopal SA., Jha NK., Ovanesov MV., Lee TK. \& Sarafanov, AG. (2012). Insect cell-based expression and characterization of a single-chain variable antibody fragment directed against blood coagulation factor VIII. Protein Expression and Purification 88(2): 201-206.

Lai H., He J., Hurtado J., Stahnke J., Fuchs A., Mehlhop E., Gorlatov S., Loos A., Diamond MS. \& Chen, Q. (2014).
Structural and functional characterization of an anti-West Nile virus monoclonal antibody and its single-chain variant produced in glycoengineered plants. Plant Biotechnology Journal 12(8): 10981107.

Lim SSY. (2012). The development of single-chain variable fragment ( $\mathrm{scFv}$ ) antibodies against Toxoplasma gondii by phage-display, Dissertation, University of Malaya.

Lim SSY., Chua KH., Nölke G., Spiegel H., Goh WL., Chow SK., Kee BP., Fisher R., Schillberg S. \& Othman, RY. (2018). Plant-derived chimeric antibodies inhibit the invasion of human fibroblasts by Toxoplasma gondii. PeerJ 6(e5780).

Lim SSY. \& Othman, RY. (2014). Recent Advances in Toxoplasma gondii Immunotherapeutics. Korean Journal of Parasitology 52(6): 581593.

Livak KJ. \& Schmittgen, TD. (2001). Analysis of relative gene expression data using real-time quantitative PCR and the 2- $\Delta \Delta$ CT method. Methods 25: 402-408.

Makvandi-Nejad S., McLean MD., Hirama T., Almquist KC., Mackenzie CR. \& Hall, JC. (2005). Transgenic tobacco plants expressing a dimeric singlechain variable fragment (scfv) antibody against Salmonella enterica serotype Paratyphi B. Transgenic Research 14(5): 785-792.

Maxmen A. (2012). Drug making plant blooms: Approval of a 'biologic' manufactured in plant cells may pave the way for similar products. Nature Biotechnology 485: 160. 
Merlin M., Gecchele E., Capaldi S., Pezzotti M. \& Avesani, L. (2014). Comparative evaluation of recombinant protein production in different biofactories: The green perspective. BioMed Research International 2014(136419).

Murashige T. \& Skoog, F. (1962). A revised medium for rapid growth and bio assays with tobacco tissue cultures. Journal of Plant Physiology 15: 473497.

Niemer M., Mehofer U., Acosta JAT., Verdianz M., Henkel T., Loos A., Strasser R.,

Maresch D., Rademacher T., Steinkellner H. \& Mach, L. (2014). The human anti-HIV antibodies 2F5, 2G12, and PG9 differ in their susceptibility to proteolytic degradation: Downregulation of endogenous serine and cysteine proteinase activities could improve antibody production in plantbased expression platforms. Biotechnology Journal 9: 493-500.

Obeme OO., Popoola JO., Leelavathi S. \& Reddy, SV. (2011). Advances in plant molecular farming. Biotechnology Advances 29: 210-222.

Omar MTC. (2017). Expression ofFunctional Anti-p24 scFv 183-H125C in HEK293T and Jurkat T Cells. Advanced Pharmaceutical Bulletin 7(2): 299-312.

Puetz J. \& Wurm, FM. (2019). Recombinant Proteins for Industrial versus Pharmaceutical Purposes: A Review of Process and Pricing. Processes 7(8): 476-486.

Rahimzadeh M., Sadeghizadeh M., Najafi F., Arab S. \& Mobasheri, H. (2016).
Impact of heat shock step on bacterial transformation efficiency. Molecular Biology Research Communications 5(4): 257-261.

Robert S., Khalf M., Goulet MC., D'Aoust MA., Sainsbury F. \& Michaud, D. (2013). Protection of recombinant mammalian antibodies from development-dependent proteolysis in leaves of Nicotiana benthamiana. Plos One 8(7): 1-9.

Sack M., Hofbauer A., Fischer R. \& Stoger, E. (2015). The increasing value of plant-made proteins. Current Opinion in Biotechnology 32: 163-170.

Sarker A., Rathore AS. \& Gupta, RD. (2019). Evaluation of $\mathrm{scFv}$ protein recovery from $\mathrm{E}$. coli by in vitro refolding and mild solubilization process. Microbial Cell Factories 18(5).

Schmidt GW. \& Delaney, SK. (2010). Stable internal reference genes for normalization of real-time RT-PCR in tobacco (Nicotiana tabacum) during development and abiotic stress. Molecular Genetics and Genomics 283(3): 233-241.

Schouten A., Roosien J., Bakker J. \& Schots, A. (2002). Formation of disulphide bridges by a single-chain $\mathrm{Fv}$ antibody in the reducing ectopic environment of the plant cytosol. The Journal of Biological Chemistry 277(31): 19339-19345.

Shoji Y., Jones RM., Mett V., Chichester JA., Musiychuk K., Sun X., Tumpey TM., Green BJ., Shamloul M., Norikane J., Bi H., Hartman CE., Bottone C., Stewart M., Streatfield SJ. \& Yusibov, V. (2013). A plantproduced $\mathrm{H} 1 \mathrm{~N} 1 \quad$ trimeric 
hemagglutinin protects mice from a lethal influenza virus challenge. Human, Vaccines, and Immunotherapeutics 9(3): 553-560.

Stelzer S., Basso W., Silvan JB., OrtegaMora LM., Maksimov P., Gethman J., Conraths FJ. \& Schares, G. (2019). Toxoplasma gondii infection and toxoplasmosis in farm animals: Risk factors and economic impact. Food and Waterborne Parasitology 15(e00037).

Takeno K. (2012). Stress-induced flowering. In H Hirt and K Shinozaki (Eds.), Abiotic Stress Responses in Plants (pp.331-345). New York, NY: Springer.

Takeno K. (2016). Stress-induced flowering: the third category of flowering response. Journal of Experimental Botany 67(17): 49254934.

Takeyama N., Kiyono H. \& Yuki, Y. (2015). Plant-based vaccines for animals and humans: recent advances in technology and clinical trials. Therapeutic Advances in Vaccine 3(56): 139-154.

Tamura M., Togami J., Ishiguro K., Nakamura N., Katsumoto Y., Suzuki K., Kusumi T. \& Tanaka, Y. (2003). Regeneration of Verbena (Verbena $\mathrm{X}$ hybrida) by Agrobacterium tumefaciens. Plant Cell Reports 21(5): 459-466.

Tizaoui K., \& Kchouk, ME. (2012). Genetic approaches for studying transgene inheritance and genetic recombination in three successive generations of transformed tobacco. Genetics and molecular biology 35(3): 640-649.
Wang JL., Zhang NZ., Li TT., He JJ., Elsheikha HM. \& Zhu, XQ. (2019). Advances in the development of antiToxoplasma gondii vaccines: Challenges, opportunities, and perspectives. Trends Parasitology 35(3): 239-253.

Wang XF., Li L., Yang T., Lui J., Fan Y., Zhu X. \& Wang, XZ. (2015). Singlechain variable fragment (scFv) expression in tobacco plants via agroinoculation. Russian Journal of Plant Physiology 62(3): 401-407.

Wang ZD., Liu HH., Ma ZX., Ma HY., Li ZY., Yang ZB., Zhu XQ., Xu B., Wei F. \& Liu, Q. (2017). Toxoplasma gondii Infection in Immunocompromised Patients: A Systematic Review and MetaAnalysis. Frontiers in Microbiology 8(389).

Wen-Bin Y., Jin-Lei W., Qian G., Yang Z., Kai C., Qing L., Qin-Li L., Xing-Quan Z. \& Dong-Hui Z. (2019). Immunization With a Live-Attenuated RH: $\triangle$ NPT1 Strain of Toxoplasma gondii Induces Strong Protective Immunity Against Toxoplasmosis in Mice. Frontiers in Microbiology 10: 1875-1887.

Yao J., Weng Y., Dickey A. \& Wang, KY. (2015). Plants as factories for Human Pharmaceuticals: Applications and Challenges. International Journal of Molecular Science 16(12): 2854928565.

Yuan X., Chen X., Yang M., Hu J., Yang W., Chen T., Wang Q., Zhang X., Lin R. \& Zhao, A. (2016). Efficient construct of a large and functional $\mathrm{scFv}$ yeast display library derived 
from the ascites B cells of ovarian cancer patients by three-fragment transformation-associated

recombination. Applied of Microbiology and Biotechnology 100(9): 4051-4061.

Yusakul G., Sakamoto S., Juengwatanatrakul T., Putalun W., Tanaka H. \& Morimoto, S. (2015). Preparation and application of a monoclonal antibody against the isoflavone glycoside daidzin using a mannich reaction- derived hapten conjugate. Phytochemical Analysis 27(1): 81-88.

Zhou X., Carranco R., Vitha S. \& Hall, TC. (2005). The dark side of green fluorescent protein. New Phytologist 168: 313-322.

Zhou X., Chandrasekharan MB. \& Hall, TC. (2004). High rooting frequency and functional analysis of GUS and GFP expression in transgenic Medicago truncatula A17. New Phytologist 162: 813-822. 